\title{
"We Have Had It Up To Here": Murder, Civil Disorder, and Civil Rights in a Western Pennsylvanian Industrial Town
}

\section{ALEX TABOR}

Abstract: In 1970, citizens of New Castle, Pennsylvania, a small industrial city an hour north of Pittsburgh, responded to the racially motivated murder of a local black Vietnam veteran in that city with vandalism and firebombing that forced the mayor to place the city under a state of emergency for three days. The series of exchanges preceding and following the murder reveals much about that city's history, and how several factors influenced local forms of racism. Existing scholarship has focused on racialized policies and practices in two spatial extremes-large cities and small towns-while this analysis seeks to illustrate how local, regional, and national influences shaped what forms of racebased policies and practices in spaces between these municipal extremes were permissible. Beyond place and space, this research contributes to a different set of conversations about the ways identity and community are articulated through the actions of individuals and groups, and how those understandings are shaped by individual and collective memory. This analysis begins by situating Ronald Mitchell's murder within the historical context of 1970s New Castle, broadens to place New Castle amid much larger and smaller municipalities across the country, and briefly contours some historical forces that shaped racism in policy or practice across time. I illustrate how federal, state, and local authorities responded to crises comparable to that which occurred in response to Mitchell's murder in the 1960s, and highlight how the underlying causes identified during investigations by those bodies manifested throughout the city's history and at the scene of Mitchell's murder. I also explore the role of institutions and memory in shaping knowledge and use of the past and build upon earlier scholarship in asserting their centrality to equitable futures. 


\section{Introduction}

On 1 November 1970, Ronald Mitchell—a black Vietnam vet and Purple Heart recipient known by friends as "Fat Man," newlywed husband and expectant father, carpenter and activist—was killed by a white shooter firing from a slowly passing vehicle shortly after midnight in New Castle, Pennsylvania, a small industrial city an hour north of Pittsburgh. Mitchell bled to death nearly one hundred feet from his home while awaiting delayed emergency services, and subsequent racist police action ignited an angry and confused crowd of black witnesses. ${ }^{1}$ Physical violence erupted, engaging officers, residents, and city administration until sunrise. That night, firebombs targeting white and ethnic businesses within the black community kept officers and firefighters occupied until the following morning. The mayor invoked a three-day State of Emergency to mitigate the tension arising from the event. Black participants were arrested, racist police action was overlooked, Mitchell's murder was never solved, and New Castle's history of racial struggle was ignored, silenced almost entirely for posterity.

I conducted oral interviews with black and white residents who had lived most, if not all, of their lives in the city. I also conducted a public outreach on social media, in the form of a post on the community's unofficial Facebook page, where I sought more information from anyone who lived through the city's three-day state of emergency. Few of New Castle's white citizens interviewed between 2016 and 2018 can recall any detail about Mitchell's murder, the violent response by black witnesses, or the fire-bombings that induced a three-day State of Emergency. Little written evidence remains to attest to the event or its significance in the city's history - a collective response to a legacy of racist policies and practices valuable for understanding relationships between people, place, and space, and the influences driving their transformation across the twentieth century. Institutions that produce or protect knowledge of different natures and purposes - like historical societies and libraries or school boards and police departments - archive knowledge reflective of the predominantly Anglo-American employees and staff, privilege sources honored and legitimized by a long-standing socioeconomic status quo defined by racist prescriptions, or obstructed, prevaricated around, or otherwise denied requests for information. The compounding

\footnotetext{
${ }^{1}$ John K. Manna, "'Quick Chain of Events Brings Confusion: Every Available Man' Called Out," New Castle News, November 2, 1970.
} 
consequence of these conditions is a silencing of the past, the forces and influences at play within it, and their lasting impact on today. ${ }^{2}$

These events provide an important segue into a century's history of racially-inflected social, economic, and political policy and practice, as well as the history of equally dynamic community organizing, in a space between well-documented urban centers and rural sundown towns - small communities that prohibited blacks and some ethnic minorities from overnight stay with threat of violence. ${ }^{3}$ What is unique

${ }^{2}$ I first encountered the idea of "historical silences" while reading Michel-Rolph Trouillot's, Silencing the Past: The Power and Production of History. Trouillot's analysis of the power and politics fundamental to and inseparable from the production of historical narrative requires a reckoning with the intentionality of omissions and an investigation of the contexts and motivations surrounding their suppression. See, Michel-Rolph Trouillot, Silencing the Past: The Power and Production of History (Boston, Massachusetts: Beacon Press, 1995). Four moments that Trouillot identifies as locations where silences are produced frame the analysis of sources that follows: "the moment of fact creation (the making of the sources); the moment of fact assembly (the making of archives); the moment of fact retrieval (the making of narratives); and the moment of retrospective significance (the making of history in the final instance)." Regarding periodization, Bayard Rustin described the decade between the monumental Supreme Court ruling in Brown v. Board of Education (1954) and the passage of the Voting Rights Act in 1965 as the "classical phase," and the perception found life in works like Gary May's Bending Toward Justice: The Voting Rights Act and the Transformation of American Democracy (New York: Basic Books, 2013). This author subscribes to a periodization of the Afro-American Civil Rights Movement that transcends interpretations that confine the movement between Brown the Civil Rights Act of 1964 and conceptualizes the Movement's origins in resistance to enslavement and evolving in form-like the racially discriminatory, exclusionary, and oppressive policies and practices levied-across changing circumstances and contexts into the present.

${ }^{3}$ James Loewen, Sundown Towns: A Hidden Dimension of American Racism (New York, London: The New Press, 2005). Several scholarly works analyze the broader freedom struggle from Reconstruction to the turn of the $21^{\text {st }}$ century. See, Jacquelyn Dowd Hall, "The Long Civil Rights Movement and the Political Uses of the Past," The Journal of American History 91, no. 4 (Mar., 2005): 1233-1263; Eduardo BonillaSilva, Racism without Racists: Color-blind Racism and the Persistence of Racial Inequality in America (New York: Rowman \& Littlefield Publishers, Inc., 2014); Ian Haney-Lopez, White By Law (New York; London: New York University Press, 2006); Deborah Gray White, Too Heavy A Load: Black Women in Defense of Themselves, 1894-1994 (New York; London: W. W. Norton \& Company, 1999); Derek Bell, Faces at the Bottom of the Well: The Permanence of Racism (New York: Basic Books, 1992); Michelle Alexander, The New Jim Crow: Mass Incarceration in the Age of Colorblindness (New York: The New Press, 2012); Douglas A. Blackmon, Slavery by Another Name: The Re-Enslavement of Black Americans from the Civil War to World War II (New York: Anchor Books, 2009); Karen E. Fields and Barbara J. Fields, Racecraft: The Soul of Inequality in American Life (London; New York: Verso, 2012). 
in New Castle is the evolving forms of racist policies and practices and the diverse functions they served when compared to well-documented urban metropoles like New York, Los Angeles, or Chicago, and rural sundown towns. Certain social, economic, and political conditions in major cities and rural towns allowed varying forms of public and private, overt and subtle, classed and gendered racism by actors operating within diverse systems to order social hierarchies, determine economic access, and inform political decision-making. ${ }^{4}$ New Castle's historical past included both the rural, settler frontier and a late-nineteenth-century urban industrial boom; the city is presently a small hub in a predominantly agricultural region. The city's rapid growth and decline provide one dimension through which the history of New Castle's black communities' mitigation of and resistance to racism can be investigated.

Settled in 1798, New Castle's position on the Pittsburgh and Lake Erie Railroad fostered the growth of a population of some 300 at its beginning to nearly 30,000 by the 1870 s. Between the 1890 s and 1940s, "Little Pittsburgh" experienced an incredible industrial boom, as changing import tariffs, increased immigration from southeast Europe,

For studies of resistance against discrimination in urban and rural extremes, see, Thomas J. Sugrue, The Origins of the Urban Crisis: Race and Inequality in Postwar Detroit (Princeton and Oxford: Princeton University Press, 2005); Kevin Mumford, Newark: A History of Race, Rights, and Riots in America (New York; London: New York University Press, 2007); Gerald Horne, Fire This Time: The Watts Uprising and the 1960s (Charlottesville, VA: University Press of Virginia, 1995); and Loewen, Sundown Towns. Importantly, Loewen does not confine the concept of sundown town to rural spaces, despite a majority existing far outside and between urban environments. Loewen explains that most suburban communities originally predicated on racial exclusion. Varying levels and uses of violence in the North by whites contributed to maintaining the segregation of sundown spaces - a conceptualization of the term I am using to analyze the existence of racialized space bound, cordoned, and policed with violence within an incorporated municipality-but Aldon Morris explains that beyond context-specific experiences, little difference existed between Northern de facto segregation and Southern Jim Crow. Unique to the Northern experience, however, and especially noticeable in New Castle, is the "unspoken" nature of the rules ordering society, often demarcated by "invisible" boundaries whose physical manifestations included railroad tracks, bridges, and main thoroughfares. For more discussion of this see, Aldon Morris, Origins of the Civil Rights Movement: Black Communities Organizing for Change (New York: The Free Press, 1984), 275-90.

${ }^{4}$ The importance of understanding the influences shaping polities like New Castle and their relation to, relationship with, and interdependence on comparable surrounding spaces is evidenced by new scholarship on the centrality of suburbs to postwar development in the United States, see especially, The New Suburban History, Kevin M. Kruse and Thomas J. Sugrue, eds. (Chicago; London: The University of Chicago Press, 2006). 
and steel industry consolidation around Pittsburgh brought New Castle into the fold of the Carnegie and U.S. Steel Companies at the turn of the century. ${ }^{5}$ The city's population peaked at nearly 50,000 in the $1950 \mathrm{~s}$, but the city endured precipitous decline following World War II, especially in a wave of 1970s deindustrialization, increasing workplace automation, and changes in global trade relationships. Presently, New Castle is a small commercial hub in a regionally agricultural area, where around a quarter of the approximately 22,000 residents experience poverty in the wake of history. ${ }^{6}$

If New Castle's balance in 1970 between rural and urban space belied the achievement of economic harmony, a review of the city's history reveals a more complex evolution. Diverse groups in New Castle's history-like ethnically "white" Italians and Polish and Slovak industrial workers, a small number of ethnic Syrian grocers and shopkeepers, wealthy Anglo-Americans atop outlying hills, and people of color predominantly of African American descent at the city's coreexperienced class and class difference, race and ethnicity, and community differently based on the coalescence of unique local histories, collective experiences, and societal positions. This historical journey provides an interesting case in which racist policies and practices respond to changing economic conditions and pervade different dimensions of existence based on forces and influences operating on multiple scales. Between major urban centers and mirroring rural counter-spaces, cities like New Castle demonstrate that varied and changing concepts of class coalesced with dynamic understandings of race and racism, and those racist policies and practices comfortably applied different dimensions of classism and racism in changing ways under evolving circumstances. This analysis will trace these themes in the stratified order of severity conveyed to investigators on President Lyndon B. Johnson's National Advisory Commission on Civil Disorders, formed by executive order in 1967, by interviewees in cities where civil disorders erupted across the preceding half-decade. This stratification ascended from interpersonal forms of social violence to de facto and de jure institutional discrimination, segregation, or otherwise unequal

\footnotetext{
${ }^{5}$ David Burcham, "More than a century ago, steel was the rage," New Castle News, February 25, 2013.

${ }^{6}$ Between 23.3-26.5\% of New Castle's population's annual income falls below the poverty level. U.S. Census Bureau, 2013-2017 American Community Survey 5-Year Estimates, accessed April 26, 2019, https://factfinder.census.gov/faces/tableservices/jsf/pages/productview.xhtml? $\mathrm{src}=\mathrm{CF}$
} 
treatment that transgressed bounds of physical, psychological, and material violence.

Analysis of the use of violence in New Castle by police and society and in resistance to economic exclusion and social circumscription by the black community reveals an important relationship between historical narrative and public memory. The "silencing" of New Castle's freedom struggle contributes to contemporary denial by whites of the structural racial inequalities predating Mitchell's murder that prefaced individual and community responses, or their contemporary consequences. Local history is a pillar of identity, and narratives embraced by local whites deny to the enduring struggle for equitable and fair treatment any historical influence within the city's broader change over time. These silences represent disparities in the power of historical production, the occupation of positions of power in social, economic, and political systems, and access to and ownership of resources - all are products of discriminatory systems maintained by whites but resisted by the city's black community, and are thus critical to understanding New Castle's history and at least some of the dynamics underlying its evolution. These silences are defended in the selection, organization, retrieval, and assignment of retrospective significance to facts of that narrative. ${ }^{7}$

Social, economic, and political power used for the purposes of exploitation, manipulation, and control across the twentieth century serve as primary sources of conflict and contestation in the context of this analysis. Silenced narratives and perspectives incorporated throughout contribute new information to extant histories. The forces influencing and shaping racist practice and community rebuke in spaces between major urban centers and contrasting rural towns present new dynamics and relationships for consideration within broader investigations of the U.S. civil rights movement.

\section{Spaces In-Between}

Across most of the South for most of U.S. history, racism frequently took form as overt policy and practice because of historically constructed social, economic, and political systems used to exercise power over and exploit African Americans, Indigenous peoples, Mexicans, and other ethnic and national minorities. In the U.S. during and following slavery, socially enforced codes of conduct displayed in communal practices and ideologically sustained by imagery and performance buttressed ideas of

\footnotetext{
${ }^{7}$ Trouillot, Silencing the Past, 26.
} 
white superiority with facades of submission by regulating and normalizing ritual performances of "race" - a term increasingly employed to characterize, explain, and justify the maintained domination of African Americans and others. ${ }^{8}$ Terroristic violence by whites served as the primary means of enforcement until shifting global contexts later forced the evolution of "lynch law" into subtler, more covert processes, some visible today in criminal justice and judicial systems. ${ }^{9}$ However, communal practices and ideology underpinned perceptions of racial

\footnotetext{
${ }^{8}$ Stephen Jay Gould evaluates the history of biological "race"-science, highlighting intellectual roots, misconceptions, and assumptions. See, Gould, The Mismeasure of Man (New York: W. W. Norton \& Company, Inc., 1996). Within their broader analysis of "race" throughout U.S. history, Fields and Fields provide several examples of how prejudice against the "otherness" historically inscribed to blackness has framed the social and cultural functions of American institutions and daily interactions between Americans of unique ancestries since the American Revolution. Nell Irvin Painter pursues similar inquiry on a transhistorical scale in The History of White People (New York: W. W. Norton \& Company, Inc., 2010). See also, Mustafa Emirbayer and Matthew Desmond, The Racial Order (Chicago: The University of Chicago Press, 2015), Michael Omi and Howard Winant, Racial Formation in the United States (New York: Routledge, 2015); and Les Black and John Solomos, eds., Theories of Race and Racism: A Reader (London: Routledge, 2009).

${ }^{9}$ A body of literature elucidates the ideologies underpinning racist beliefs, which often varied in biological, cultural, social, economic, and political content and obligation, and several investigate the pestilence of lynching as an act of brutal, dehumanizing violence and communal identity-making. See, Winthrop Jordan, White Over Black: American Attitudes Toward the Negro, 1550-1812 (Kingsport, TN: The University of North Carolina Press, 1968); Ida B. Wells, Southern Horrors, Lynch Law in All Its Phases (New York, 1892); and Cynthia Skove Nevels, Lynching to Belong: Claiming Whiteness Through Racial Violence (College Station: Texas A\&M University Press, 2007). See, James Allen, ed., Hilton Als, Congressman John Lewis, and Leon F. Litwack, Without Sanctuary: Lynching Photography in America (Santa Fe, NM: Twin Palms Publishers, 2000), https://withoutsanctuary.org. The Equal Justice Initiative's December 2018, report Lynching in America: Confronting the Legacy of Racial Terror documents 4,075 "racial terror" lynchings in "twelve Southern states during the period between Reconstruction and World War II," and provides historical context. See, https://lynchinginamerica.eji.org/report/. Topical literature also attends to lynching of other ethnic minorities in U.S. history. In Cold War Civil Rights, Mary Dudziak illustrates the relationship between civil rights and domestic policy in the United States and international reputation throughout the mid-twentieth century, especially the role of media in presenting circumstances in the United States within changing social and political contexts abroad during the Cold War. See, Mary L. Dudziak, Cold War Civil Rights: Race and the Image of American Democracy (Princeton, NJ: Princeton University Press, 2000). Nicole Gonzalez Van Cleve expounds on the psychological consequences of racially imbalanced police forces and criminal justice systems, and how those imbalances translate into and are internalized as tautological stereotypes, see, Crook County: Racism and Injustice in America's Largest Criminal Court (Stanford: Stanford University Press, 2016).
} 
difference and black inferiority across many spaces in the North also, ordering social hierarchies and normalizing displays of punitive violence by the general population.

In poor and economically unstable spaces across the North, where differences in generational property ownership and accumulated wealth frequently remained too small for the privileging of class-based understandings of difference and for curated distribution of economic power, racist policies and practices often resembled those designed to maintain antebellum hierarchies of power. In areas of low economic diversity, racist social practices and political circumscription maintained white understandings of difference. In areas characterized by greater economic diversity, class-based proxies for racist policy-like discriminatory loan and lending practices that segregated racial and ethnic minorities to the least valued land in most cities - served to mark difference with greater salience than unbridled violence. This is not to say that unrestrained violence did not serve to communicate place and belonging, especially across the early twentieth-century North, but rather to highlight the economic nature of many acts of racist violence emerged in competition over, or fear of separation from, privileged access to economic resources. Sumptuary codes enshrined etiquette and performance standards predicated on white superiority and black deference into formal law. Unbridled violence synonymous with lynch law ensured complicity. De facto state sanctioning through the frequent oversight and participation by law enforcement often precluded questions of serious legal recourse, which the criminal justice system affirmed. Poll taxes, literacy tests, land ownership and sex requirements, and other discriminatory disenfranchisement mechanisms combined with unrestrained violence to limit the exercise of voting rights. In the absence of significant economic diversity, the roots for notions of economic class difference lacked fertile soil and no class-guised proxy existed for masking historically created and generationally maintained beliefs in racial superiority. Racist social and political practices remained methods of sustaining extant ideas of difference and systems of power for posterity.

While Northern cities may have lacked much of the infrastructure of overt institutions of slavery, racial discrimination was nonetheless perpetuated through economic policies and practices. ${ }^{10}$

\footnotetext{
${ }^{10}$ In describing chattel slavery in the United States as the peculiar institution, historian Kenneth M. Stampp explained that "Southerners did not create the slave system all at once in 1619; rather, they built it little by little, step by step, choice by choice, over a
} 
Control over employment opportunities, workplace stratification, hiring practices, and wages; oversight of the allocation and distribution of financial assets for community development, improvement, and welfare; and the power to define property values and zoning ordinances and approve building licenses, permits, credit, and loans. All reflected racial discrimination and its consequences but presented disparities in power as products of economic policies formally functioning for an array of purposes, informally grounded in racism for the maintenance of power. In major cities where economic diversity fostered recognizable differences in economic class - whether defined by economic position or status, property ownership, or wealth-racist economic policies and financial practices outlasted overt social practices and political machinations faced by greater judicial and international scrutiny.

In no two urban metropoles, rural towns, or spaces in-between does the balance and relationship between social, economic, and political power, or their distribution and exercise, function in the same manner or produce the same outcomes. Likewise, no experience with any raciallyinflected policy or practice falls exclusively under the label social, which I use to refer to interpersonal and group relations; economic, wherein I refer primarily to financial practices and interactions over material resources; or political, which I apply in reference to activity within the purview of government, quasi-government, juridical, or otherwise institutional systems. Unique histories of locations, economic conditions, social practices, and political relationships all influence how racism manifests in policy and practice. Nonetheless, similar conditions and trends among rural and urban spaces within geographic regions do often share similarities.

\section{"A Young Negro...Slain": Community Response to the Drive-By Shooting of Ronald Mitchell}

Ronald Mitchell left his home late Saturday evening for a short visit with his brother-in-law at the Rainbow Gardens bar only a few doors down the street. ${ }^{11}$ His wife of nine months, Jennie, remembered hearing him

\footnotetext{
period of many years." See, Kenneth M. Stampp, The Peculiar Institution: Slavery in the Ante-Bellum South (New York: Vintage, 1956).

11 "Housing Ceremony Picketed: Black Citizens Protest Hiring," New Castle News, June 2, 1970; John K. Manna, "Quick Chain of Events Brings Confusion: 'Every Available Man' Called Out," New Castle News, November 2, 1970; Mike Matis, "Shooting Touches Off Violence," continued as, "Shooting Starts Violence," New Castle News, November 2, 1970; "BCC Hears Eye Witness," New Castle News, November 2, 1970.
} 
say he would be "back in a few minutes." Six months pregnant with their only child at the time of his death, she wept to recall "he had just come home from Vietnam" the previous year. ${ }^{12}$ He worked in the Spring Division at Rockwell Automation, producing springs for automobile axels at one of the local manufactories, and "everyone in...town knew him, they liked him. He was a nice guy" and "was never in trouble." ${ }^{\text {"3 }}$ Autopsy reports declared Mitchell "dead on arrival" at the St. Francis hospital, having succumbed to a puncture in the abdominal region that resulted in excessive bleeding and subsequent organ failure- $a$ succession of medical needs that might have been stopped had Mitchell received sufficient medical attention in a timely manner that morning. ${ }^{14}$ However, emergency services did not arrive for thirteen minutes although stationed only four blocks away from the shooting. Moreover, as Mitchell bled to death within sight of his home as he waited for the ambulance to travel one mile, the police arrived within minutes. ${ }^{15}$ In effect, black witnesses, already angered, upset, and confused by Mitchell's shooting, were faced by the aggressive provocation of arriving police officers in lieu of medical help. ${ }^{16}$ Black residents battled police officers in the ensuing conflict, and the following evening some black residents firebombed several white businesses. ${ }^{17}$

Police sealed Long Avenue between Mill and Moravia Streets, which outlined New Castle's predominantly black South Side community, shortly after news of Mitchell's shooting at 12:30 a.m. Both

\footnotetext{
12 Jennie Mitchell, personal interview by author, September 20, 2014, interviewee's home.

${ }^{13}$ Mitchell, interview. Details about work conducted by Rockwell's Springs Division derive from a recent New Castle News article in which writer Lugene Pezzuto interviewed members of the Division attending a reunion in August 2017. See, Lugene Pezzuto, "Former Rockwell Springs Division Employees Reunited, Reminisce," New Castle News, August 7, 2017.

${ }^{14}$ Mike Matis, "Shooting Touches Off Violence," continued as, "Shooting Starts Violence," New Castle News, November 2, 1970.

${ }^{15}$ Ibid.

${ }^{16}$ New Castle Police Department Lieutenant Dan Malley "admitted ... he 'may' have made the statement 'what are you waiting for now, the stakes are even,' to the crowd when police enforcements arrived to calm the situation." NCPD Chief Richard Hanna was also accused of acting on his recognition of one rioter, Lennie Payne, who earlier passed the department's physical and written examinations, but failed the oral exam facilitated by Chief Hanna. Payne would have been the third black police officer in a department of sixty-one. See, Dick Robbins, "Acquitted on Other Charges: Payne Found Guilty of Riot," New Castle News, March 2, 1971; "BCC Hears Eye Witness," New Castle News, November 2, 1970.

${ }^{17}$ Matis, "Shooting Touches Off Violence," continued as, "Shooting Starts Violence," New Castle News, November 2, 1970.
} 
streets served as borders on New Castle's residential security map, produced in 1928, upon which insurance companies and lending agencies based disinvestment of black communities by denying loans and subsidy. ${ }^{18}$ "An angry mob was breaking windows," and when vandalism and word of an attack on John Aeschbacker - the white man believed by black witnesses to have shot and killed Mitchell—spread, the lieutenant commanding New Castle Police Department's south side station immediately requested assistance from other officers. Shortly after, and with greater urgency, the lieutenant exclaimed that "a car had been upset" and "an apparent brawl" had ignited. "Send every available man," he begged. ${ }^{19}$

The altercation between police and black witnesses barely lasted one minute, but a remarkable amount of human injury occurred in that time. Alongside Ronald Mitchell's blood on the streets of New Castle early that Sunday morning was that of at least nine others, including that of at least five police officers, two women, and Mitchell's alleged assailant, John Aeschbacker. In fact, the altercation occurred in defense of Aeschbacker, as police recognized a threat to his life by the crowd that enveloped him, unconcerned about the life taken less than an hour earlier. ${ }^{20}$ Aeschbacker's "car had been overturned," and he was "pulled out, beaten and stabbed several times," in the abdomen, back, and left forearm. ${ }^{21}$ One officer was stabbed in the left shoulder, stones injured others, and two incurred back and head injuries, one being knocked unconscious. The testimony of one of three black men arrested provides the only information about the injuries of black participants. Lennie Payne reported receiving two hits to the back while engaging with New Castle Police Chief Richard Hanna. ${ }^{22}$ The arrival of a small detachment

\footnotetext{
${ }^{18}$ See, Appendix B.

${ }^{19}$ Manna, "Quick Chain of Events Brings Confusion: 'Every Available Man' Called Out," New Castle News, November 2, 1970.

${ }^{20}$ Matis, "Shooting Touches Off Violence," continued as, "Shooting Starts Violence," New Castle News, November 2, 1970; Manna, "Quick Chain of Events Brings Confusion: 'Every Available Man' Called Out," New Castle News, November 2, 1970; Robbins, "Acquitted On Other Charges: Payne Found Guilty Of Riot," New Castle News, March 2, 1971.

${ }^{21}$ Matis, "Shooting Touches Off Violence," continued as, "Shooting Starts Violence," New Castle News, November 2, 1970.

${ }^{22}$ Underlying conflict between Chief Hanna and Payne emerged during testimony surrounding the murder and physical engagement with police, during which the New Castle Police Department's racially discriminatory hiring practices came to light. Matis, "Shooting Touches Off Violence," continued as, "Shooting Starts Violence," New Castle News, November 2, 1970. It must be noted that, despite aggressive and racist actions of members of the NCPD, Pennsylvania State Police Officers, who arrived near
} 
of eight state police officers and mediation by black leadership successfully mollified the crowd remaining near the scene on Long Avenue. As crowds dissipated, "an uneasy calm rested over the area," and with daybreak, "police, blacks and whites searched for answers to try and make some kind of sense from the whole thing." 23

The following morning, the New Castle News, the city's primary newspaper, reported that "broken glass was lying everywhere and practically every building had been the target of a rock throwing spree...[W]indows, many of them large store windows, were broken in the several hours of vandalism." ${ }^{24}$ The vandalized properties symbolized historical discrimination, segregation, and racism in New Castle. Neighborhood supermarkets operated by ethnically-white Italian, Polish, Slovak, and sometimes Serbian community members daily reminded black residents of their distance from the mainstream economic resources; lumber yards safeguarded the material resources untouched by black tradesmen barred from unions and not hired on job sites. ${ }^{25}$ Police arrested three young men between early morning and afternoon, charging them with rioting, disorderly conduct, and obstructing police officers, one additionally charged with assault with intent to kill and aggravated assault and battery. The arrests failed to assuage whites angry about the vandalism and added to the outrage felt by the black community, which viewed Mitchell's murder as one more incident in a long history of racist civil rights violations, one more embodiment of the city's overarching structures of inequality.

From just after sunset until sunrise Monday morning, firebombs kept New Castle's South Side ablaze, literally and symbolically expressing the anger felt by members of the black community. ${ }^{26}$ "When

\footnotetext{
the end of the altercation, confirmed NCPD officers did not draw guns or rifles throughout the event.

${ }^{23}$ Manna, "Quick Chain of Events Brings Confusion: 'Every Available Man' Called Out," New Castle News, November 2, 1970.

${ }^{24}$ Matis, "Shooting Touches Off Violence," and, "Shooting Starts Violence," November 2, 1970.

${ }^{25}$ Rombach, "Firebombs Riddle City Last Night," November 2, 1970. Montgomery's recollection of the evening of firebombings, quoted below, seems to imply that actors also targeted, if not primarily or to the same extent as other symbols, police vehicles and the mechanisms of control they represented and transported.

${ }^{26}$ The Old Farmer's Almanac notes that in New Castle, Lawrence County, Pennsylvania, on Sunday, November 1, 1970, darkness replaced the sunset around 7 p.m. and effective moonrise did not occur until after 9:30 p.m. The fire bombings occurred between 8:39-8:58 p.m., then once more, possibly selfreigniting, at 11:00 p.m., burning into Monday's early hours. The sun rose shortly before 7 a.m. Monday morning. See, Rombach, "Firebombs Riddle City Last
} 
Fat Man got shot," Melvin Montgomery, a lifelong resident of New Castle's black community, explained, "They was right there on the South Side," and word "made it to the West Side" that "they just shot him. White dude shot him, da-da-da-da-da." 27 The following night "cops was coming in the projects and...going round in a circle." "We're standing on top of this...main building...right on Grant Street," he continued, and "they're riding by...I remember tossing" and "almost hitting the car." 28 Glass Pepsi bottles and gasoline purchased at nearby gas stations functioned as explosives for which fuel-soaked rags provided fuses.

"Seven firebombings that riddled New Castle last night could have a damage bill in excess of $\$ 250,000$," the News claimed hours after the last flames had been extinguished. Five firebombings scarred the South Side at and surrounding the scene of Mitchell's murder, the article continued, also noting that police reported no injuries or arrests and suspected the prior evening's killing and altercation as the bombers' impetus. News writer Rich Rombach provided a detailed timeline of the night's events for local readers:

The first bombing took place at Baxter Heating and Roofing at $8: 39$. Fires then broke out at Rainbow Gardens at 8:40, Joseph's Warehouse at 8:41 and A.M. Supermarket at 8:43. Then at 8:58 the West Side became active as a firebomb was set off in the rear of McCormack Trucking Co. on Grant St. ${ }^{29}$

New Castle Lumber Co., also on Grant Street, was targeted shortly after and briefly reignited a second time around 11 p.m., as did the Rainbow Gardens. $^{30}$

\footnotetext{
Night," November 2, 1970. The Old Farmer's Almanac for New Castle on November 1, 1970, is accessible at, https://www.almanac.com/astronomy/rise/PA/New\%20Castle\%2C\%20Lawrence \%20County/1970-11-01. Prior to recording, Montgomery briefly reminisced upon the use of Molotov cocktails during one period of special violence, fortuitously the event he recalled was the response to Mitchell's murder. When revisited during our interview, he added that he remembered officers "stopping on the street, but they never did arrest nobody." "I remember getting the gas and the Pepsi bottles, them hard Pepsi bottles" he added, with "little rags hanging out" providing fuses.

Guthery and Montgomery, interview.

${ }^{27}$ Guthery and Montgomery, interview.

${ }^{28}$ Ibid.

${ }^{29}$ Rombach, "Firebombs Riddle City Last Night," November 2, 1970; "Firemen Find Night Quiet," New Castle News, November 3, 1970.

${ }^{30}$ Rombach, "Firebombs Riddle City Last Night," November 2, 1970; "Firemen Find Night Quiet," New Castle News, November 3, 1970.
} 
Targets of firebombing symbolized economic access unavailable to African Americans in New Castle and their locations indicate an awareness of historically established, socially understood, and legally buttressed boundaries between black and white. ${ }^{31}$ Two of the seven firebombings targeted businesses on streets that functioned as borders between "red" and "yellow" spaces on that city's earliest known residential security map produced in 1928. Interviews with lifelong residents corroborated in explaining that the spaces delineated by the redlining map framed and influenced socially understood boundaries. ${ }^{32}$ One participant in the firebombing on Grant Street noted its demarcation of the accepted northern boundary of black movement within the city. During separate interviews, Paul Ward, president of the BCC-New Castle's most active civil rights organization at the time-and Anna Mary Mooney, a white, long-term substitute teacher at the nowcondemned predominantly black Lincoln Garfield Elementary School on Long Avenue and member of several community organizations, both identified the Jefferson Street and Washington Street bridges as locations black residents - through the unspoken practice and understanding of all New Castle residents-were not to cross. ${ }^{33}$ These bridges marked the southern and western boundaries of the space whose northern and eastern edges police reified and reinforced in cordoning the "riot" scene, boundaries subsequently contested by firebombing. ${ }^{34}$

${ }^{31}$ Rich Rombach, "Firebombs Riddle City Last Night," New Castle News, November 2, 1970. See, Appendix B.

${ }^{32}$ Denise Guthery and Melvin Montgomery, personal interview by author, December 21, 2017. Denise Guthery, a lifelong resident of New Castle and volunteer at the Lawrence County Historical Society, indicated a similar understanding of Grant Street as a socially understood boundary past which blacks faced prejudicial scrutiny from white residents and police. Denise Guthery, personal interview by author, December 21, 2017.

${ }^{33}$ Anna Mary Mooney, personal interview by author, September 11, 2014; Paul V. Ward, personal interview by author, September 19, 2014.

${ }^{34}$ The same borders established in earlier generations, depicted on documents like the city's insurance redlining map, referenced by black and white interviewees, and confirmed in published statements by New Castle real-estate chairman Cecil Stubbs, are illustrated by this event. Just as the police cordon line reflected the eastern boundary of black space established on Mill Street, fire bombings on Grant Street imply an understanding by perpetrators that this street marked the formerly established, and likely commonly understood, northern boundary of that same space. Interviewees Naomi Gatewood, Anna Mary Mooney, and Paul Ward each remarked, on separate occasions and without prompting, street names that were understood to demarcate borders black and white space. The power of residential security maps to dictate the future demise or development of any given area increased exponentially with the adoption of their use by New Deal organizations like the Home Owners' Loan Corp in 
The energy summoned by Mitchell's murder reduced to a smolder by sunrise. Just before 9 a.m., and having already sought a conference with City Council members, Mayor Carl A. Ciallela, Jr. invoked a State of Emergency, which lasted for three days before tensions receded, permitting a return to some semblance of normalcy. ${ }^{35}$ In addition to physical damages of more than a quarter of a million dollars, the effects on relations between black and white residents marked the city for years to come. ${ }^{36}$ While the events following Mitchell's murder were unprecedented in New Castle-fomenting tensions long accumulating within the community-similar events occurring across the country in larger metropolitan spaces provide several cases for comparison, each revealing contests influenced by unique historical conditions and evolving social, economic, and political dynamics. ${ }^{37}$

President Lyndon B. Johnson formed the National Advisory Commission on Civil Disorders by executive order in 1967 following a half-decade of urban civil unrest, responding to a series of assassinations of civil rights leaders rooted in a centuries-unfulfilled promise of equal citizenship and concomitant rights and freedoms. The commission's objective was to identify what incited the widespread unrest and what might be done to prevent similar disorders in the future. The commission published the Kerner Report, named after Illinois Senator Otto Kerner who served as chair, where the commission's results illustrated several tiers of grievances stratified by experienced severity. At the lowest level of perceived offense were experiences with disrespectful white attitudes, discriminatory administration of justice and consumer and credit practices, and inadequate federal and welfare programs and municipal services. On the second of three levels of intensity were inadequate education systems, poor recreation facilities and programs, and ineffective grievance mechanisms and political structures. Most pressing

\footnotetext{
the 1930s. See Richard Rothstein's The Color of Law: A Forgotten History of How Our Government Segregated America (New York: W. W. Norton \& Company Ltd., 2017) for more on residential security maps and other segregating mechanisms and practices. ${ }^{35}$ Rombach, "Firebombs Riddle City Last Night," November 2, 1970.

${ }^{36} \mathrm{Ibid}$. According to the U.S. Bureau of Labor Statistics inflation calculator (https://www.bls.gov/data/inflation calculator.htm), \$250,000 of damages in 1970 is equivalent to $\$ 1,623,787.88$ in November 2019 .

37 The National Advisory Commission on Civil Disorders provided detailed accounts of eight "riot" cities but referenced conditions in others to provide historical context. While these accounts independently provide significant data for comparison, a large body of scholarly work has since expounded on these and other cases.
} 
were police practices, unemployment and underemployment, and inadequate housing. ${ }^{38}$

\section{New Castle's "Long History"}

Disrespectful white attitudes framed daily life in New Castle. The social consumption of racial tropes performed in minstrel shows throughout the early twentieth century provided one means of creating community and reinforcing white social superiority, and racialized messages inscribed onto the built environment decorated the industrial city's past. ${ }^{39}$ For example, Denise Guthery, a lifelong resident of New Castle's white community, and Melvin Montgomery acknowledged the contentious implications of lawn statues popular into the 1960s that depicted a black male servant holding a lantern. Commonly used to light porch steps, Montgomery explained that the statues connoted a subordinate status symbolic of slavery. One means of resistance to the sumptuary implications imbued within the built environment - the emblazoning of racial symbology onto property with ornaments indicative of ownership and status-entailed the throwing of such statues through the wraparound bay-windows of their owners' homes, Montgomery recalled. ${ }^{40}$

In addition to the inscription of racial hierarchies in community symbols, racial hierarchies evidenced how federal welfare programs routinely failed to address the needs of New Castle's black community, and members regularly attacked the disproportionate whiteness of decision-making bodies and prevarication in the face of black constituents' frustrations. Community groups held the local government responsible for the failure of several proposed developments and derided

\footnotetext{
${ }^{38}$ Sean Wilentz, ed. The Kerner Report: The National Advisory Commission on Civil Disorders (Princeton, Oxford; Princeton University Press, 2016), 8.

${ }^{39}$ The New Castle Herald, "New Castle Tin Mill Plan Banner Night," March 4, 1920. For more about blackface minstrelsy and the American working class, see Eric Lott, Love and Theft: Blackface Minstrelsy and the American Working Class (New York: Oxford University Press, 1993).

${ }^{40}$ Montgomery reminisced on throwing lawn ornament statues of black lawn-jockeys upholding a lantern while flashing a wide-grinned white smile, the tropes meant to elicit connotations of obeisant and subservient black service to white employers, through the bay windows of homes whose properties they marked. "We used to throw the statues through the windows," he explained, viewing the exchange as equalizing, "an eye for an eye." The use of coded racial symbology placed upon or ordered into the built environment as devices of disruption, violence, and destruction provided one mode or repurposing their meanings in forms of resistance. Guthery and Montgomery, interview.
} 
representatives for misleading black community leaders. ${ }^{41}$ In a dispute over housing development for and within the black community, numerous community members assailed a Council recommendation that recently razed single-family homes be replaced with multi-family townhouse units. The West Side community argued that replacing single-family homes with multi-family townhouse units reduced property values, confined the present population within a smaller geographic space, and limited future community growth. ${ }^{42}$ Also, multifamily housing units served lower incomes and therefore produced a smaller tax base incapable of supporting the necessary expansion of municipal services to the area. A so-called urban blight label accompanied the inexorable dilapidation of such spaces, priming them for leveling as part of so-called urban renewal projects. Various black community organizations in New Castle sometimes disagreed over which one represented the legitimate voice of the city's black community best, but all agreed that municipal government consistently failed to recognize and address that community's needs; decisions made by municipal organizations and institutions affecting New Castle's black community ordinarily subsumed its interests to those of white businesses.

With the Home Owners' Loan Corp reliant on the city's 1928 residential security map, New Castle followed the national trend of segregating minorities into ghettos located in the least desirable areas of the city and disqualifying those areas from loans and subsidies. Disqualified areas, barred from outside investment, experienced rapid economic divestment and concomitant decline, excluded from mainstream economic networks. ${ }^{43}$ Paul Ward elaborated on the

\footnotetext{
${ }^{41}$ George Mihalcik, "Center Directors Quiz Razzano, George on Finances," New Castle News, August 27, 1969; "Concern Expressed by PAL," New Castle News, March 31, 1971; Rich Rombach, "Housing Problem Discussed," New Castle News, October 13, 1971; "PAC Will Explain to PAL," New Castle News, January 21, 1972; "PAL Asks Seat on Commission," New Castle News, February 16, 1972; Rich Rombach, "West Side Housing Problem Still," continued as, "West Side Housing Aired," New Castle News, March 24, 1972.

42 Rich Rombach, "Housing Problem Unsolved," continued as, "Housing Problem Discussed," New Castle News, October 15, 1971.

${ }^{43}$ Many works highlight the consequences for urban spaces experiencing white flight, capital flight and economic disinvestment, and discriminatory policy and practice, some influential to this analysis include, Arnold R. Hirsch, Making the Second Ghetto: Race and Housing in Chicago, 1940-1960 (Chicago and Urbana: The University of Chicago Press, 1985); James R. Grossman, Land of Hope: Chicago, Black Southerners, and the Great Migration (Chicago and London: The University of Chicago Press, 1989);

Douglas S. Massey and Nancy A. Denton, American Apartheid: Segregation and the
} 
demarcated borders and boundaries reinforced by police stops that complicated desegregation and limited black mobility, explaining that "you had unwritten restrictions and you had to know them and that was your responsibility. That was the way society was at the time."44 Montgomery explained that though some poor whites and ethnic minorities lived in traditionally black neighborhoods, no blacks owned homes in white neighborhoods. If a socially understood color line did not exist for people of color, financial barriers further ensured that no blacks possessed the capital necessary for outmigration. ${ }^{45}$

In one example, when the first black family, that of a doctor esteemed within the black community, attempted to move into her East Side neighborhood while attending junior high school, Denise Guthery remembered her parents discussing the implications on the neighborhood's future. Melvin Montgomery, an acquaintance of the doctor's family, explained that lending agencies attempted to discourage and stall the doctor's purchase by significantly delaying the approval of credit. ${ }^{46}$ Mobility was a power whose exercise by the black community was heavily monitored and scrutinized. Boundaries emblazoned on the city's insurance redlining map in 1928 reflected those socially accepted by whites at that time and cemented their literal and symbolic influence over the life opportunities of black residents in the foreseeable future. ${ }^{47}$

Black ghettos existed on "the West Side and the South Side," Ward explained, adding that "if you were black and crossed the Jefferson Street bridge...you better know somebody down there or you would have to fight your way back. That was a fixture. ${ }^{148}$ Mooney described a similar division, explaining that policy and practice segregated black citizens to the South and West sides of town while white residents lived predominantly in the North and East. Cecil Stubbs, a New Castle realestate chairman, explained that many black families were "being relocated" due to "urban renewal" projects and were "unable to buy a

Making of the Underclass (Cambridge, London: Harvard University Press, 1993);

Sugrue, The Origins of the Urban Crisis; and Kruse and Sugrue, eds., The New

Suburban History.

${ }^{44}$ Ward, interview.

${ }^{45}$ Montgomery, interview

${ }^{46}$ Guthery, interview; Ibid.

${ }^{47}$ See, Appendix B.

${ }^{48}$ Ward, interview. Gatewood recalled: "You better not go past Jefferson Street ...

[W]e weren't allowed past ... You got to the top of the hill and they [police] were right there ... You [were] going no further. It was really plain ... You knew your boundaries," and "you definitely knew that ... it was your color." Gatewood, interview. 
house anywhere else than the West Side." ${ }^{49}$ The gentrification of innercity property and white flight coincided with what insurance and construction companies contracted by local officials classified as renewal and redevelopment projects. ${ }^{50}$ Public housing projects filled only a few lots razed in the name of urban renewal, part of a much larger area "that insurance companies...consider[ed] as being too big a risk." 51 Contentions over zoning ordinances and urban planning provided several instances of discord between the white city administration and black residents. ${ }^{52}$

"They had us down by the railroad tracks," Ward remarked, "this was the poor section of town."53 "Housing was segregated," Mooney added. "There was an imaginary red line around certain parts of the city...A black person did not buy a house past where the hills crested...All the white people lived up on hills and the black people downtown." ${ }^{54}$ It was the base of the hills ascending in all directions from New Castle's industrial core that marked the barriers of black housing availability. ${ }^{55}$ Similar to most urban spaces that experienced the outmigration of whites and businesses and the concomitant decline in centralized capital and investment, housing values increased with elevation and distance from that space. Mooney described a topographic

${ }^{49}$ New Castle News, "BCC to Meet to Discuss Craft Unions," June 8, 1970.

${ }^{50}$ Susan Linville, "1950s saw tide of downtown demolition start to roll in," New Castle News, May 27, 2017.

${ }^{51}$ Cecil Stubbs explained the "inconvenience" experienced by blacks forced to relocate because of "urban renewal" as "necessary." See "BCC to Meet to Discuss Craft Unions," New Castle News, June 8, 1970; "Lot Happened in a Short Time," New Castle News, November 23, 1970.

${ }_{52}$ Mike Matis, "County Revises Planning for West Park Development," New Castle News, June 3, 1970; Frederick H. Treesh, "Hope for the Cities: Planned Use of Land Vital to Future," New Castle News, June 3, 1970; "County Protests Mandated Programs," New Castle News, June 3, 1970; "Building Trades Council is Lauded for Riverside Housing Project," New Castle News, June 3, 1970; "Two Parks Approved in Union," New Castle News, November 2, 1970; John K. Manna, "Proposed Zoning Ordinance Scored by Seventh Warders," New Castle News, April 2, 1971; "Township May Lose Funds," New Castle News, May 10, 1971; Noman Kempster, "Real Estate: Government Planner Hits Zoning in Suburbs," New Castle News, September 4, 1971; "Application for City Renewal Grant OKd," New Castle News, September 28, 1971; John K. Manna, "Redevelopment Brings Questions from People," New Castle News, January 28, 1972; and John K. Manna, "'Instant Housing' Not Quick Here," continued as, "'Instant Housing' In City Neither Quick, Nor Cheap," New Castle News, February 25, 1972.

${ }^{53}$ Ward, interview.

${ }^{54}$ Mooney, interview.

${ }^{55}$ Ibid.; Guthery and Montgomery, interview. 
spread of the city that matched with near-precision the spatial geography portrayed on New Castle's 1928 redlining map. Downtown was "a valley," a "very depressed area," she explained, that housed "two very large projects" while "all the residential areas were on top of hills." 56 Though some poor whites lived in predominantly black communities, economic and physical policing retained white-dominated hills and prohibited the integration of white, middle-class neighborhoods. Upperclass residents lived in outlying boroughs where children attended schools segregated by barriers to affordable housing that excluded the highest-earning black residents of New Castle. ${ }^{57}$

The disproportionate burden placed upon New Castle's black community for fulfilling the mandates of desegregation compounded widespread fears within that community of the social, intellectual, and interpersonal dangers black students faced in white classrooms. New Castle's junior and senior high schools, though officially integrated, reflected the racial imbalance dictated by segregated neighborhood elementary schools. Experiences with segregation in elementary and middle-level education compounded racial ideologies exhibited by parents and older generations in Anglo-normative social spaces, manifesting in numerous conflicts between black and white students. ${ }^{58}$ Despite the Brown decision in 1954 mandating integration with "all deliberate speed," New Castle did not confront integration until sixteen years later, when following a statewide push for integration that had requested the same of seventeen other school districts by June 1970, a committee was called to formulate a desegregation plan for the community. ${ }^{59}$ New Castle's committee included representatives from numerous administrative, civil rights, local and municipal government bodies. After several meetings with community members and state government representatives, however, it determined to close the West Side school that served black children living in West- and South-side projects and to bus those students to the formerly whites-only school rather than to bring white students into the neighborhood. ${ }^{60}$

\footnotetext{
${ }^{56}$ Mooney, interview.

${ }^{57}$ Ibid.; Kruse, Sugrue, eds., The New Suburban History.

${ }^{58}$ Mooney, interview; Guthery and Montgomery, interview.

${ }^{59}$ Oliver Brown et al. v. Board of Education of Topeka et al., 347 U.S. 483; Oliver Brown et al. v. Board of Education of Topeka et al. 349 U.S. 249; "Ostrowski to Head Integration Group," New Castle News, July 24, 1970; and Paul Ward, "BCC Expresses Opinion on Integration Plan," New Castle News, November 18, 1970. 60 "Black Modeling Program Slated: Human Relations Commission Endorses Police Cadet Corps," New Castle News, June 9, 1970; "City Schools Desegregation Conferees Named," New Castle News, June 9, 1970; "Ostrowski To Head Integration Group,"
} 
Confronting the inequitable decision, Paul Ward alleged at a subsequent board meeting that the committee was "asking one area to bear the whole burden in a community problem." He noted the disproportionate burden placed on black students being taken from a school in their community and bussed into predominantly white neighborhoods and alluded to the social and psychological challenges facing black students in those social and educational spaces. ${ }^{61}$ Outrage and resistance to the school integration plan mirrored the extent to which it defied understood boundaries; black children were bussed to John F. Kennedy High School despite its location in a white neighborhood that criminalized the color of their skin. ${ }^{62}$ In addition to having no black teachers, black students confronted the overwhelming changes with no support. Ward lamented, "we do feel that it is a miracle" that black students, "overwhelmed by an unsympathetic majority...can function at all."63

New Castle's desegregation plan embodied one of several community dialogues that revealed and reinforced the limitations of the black population's collective power. All expressions of dissatisfaction with the committee's decision fell on deaf ears. ${ }^{64}$ The historical,

New Castle News, July 24, 1970; and Dick Garcia, "Alternate Plan Offered Board by West Side," continued as, "Alternate Plan is Offered," New Castle News, November 24, 1970.

${ }^{61}$ Paul V. Ward, "BCC Expresses Opinion on Integration Plan," New Castle News, November 18, 1970.

62 "Alternate Plan is Offered," New Castle News, November 24, 1970. Mooney recalled that "maybe 5-6 graduated," referring to black students, confirming many South- and West-Side residents' concerns. Mooney elaborated across several conversations the tension that existed between black and white students in New Castle's historically integrated high school. Districting unofficially and imperfectly segregated the city's middle-schools, and interviewees explained that most black students attended George Washington Middle School and white students Benjamin Franklin Middle School. Black elementary school students attended the North Street and West Side neighborhood schools, and whites attended Croton, Highland, or Lockley. When Guthery remarked that "I don't think it was on purpose," Montgomery laughingly noted that segregation never occurred on accident.

Similar to how white schools with white teachers stigmatized black students in New Castle, regional predominantly white districts also racially stigmatized New Castle High School's black student body. Guthery and Montgomery recalled several instances of violent conflict between Ambridge High School's rural white student body and New Castle's comparatively urban blacks. Tensions erupting among and between student populations in the years preceding Mitchell's murder mirror those simultaneously escalating across the country. Guthery and Montgomery, interview. ${ }^{63}$ Ward, "BCC Expresses Opinion on Integration Plan," November 18, 1970.

${ }^{64}$ Ward, interview; Gatewood, interview. 
invariable whiteness of City Council and other local government offices demonstrated the limits of black electoral power. Though New Castle's black population mitigated constraints by forming several politicallyoriented activist groups-including the Black Concerned Citizens and Political Action League - and was among the first fifty cities to establish a local branch of the NAACP in 1918, city leadership commonly ignored or downplayed expressions of the black community's political interests.

Neither did the black community's voice produce change when criticizing the racial imbalance of New Castle's police force. Black residents commonly asserted that a dual justice system existed in the city, seen particularly in exchanges between the police and members of the black community. ${ }^{65}$ One interviewee explained that police commonly targeted blacks while ignoring violent white aggressors - whose actions spanned from the common use of racial slurs to physical attacks and workplace cross burnings - on the occasions that police were not the latter. ${ }^{66}$ For example, the attention given Mitchell the morning of his murder paled in comparison to the defense provided John Aeschbacker, the white man who police immediately sought to protect from blacks desirous of enacting revenge. It was with this in mind that bystanders and witnesses excoriated New Castle Police Department and pointed to Mitchell's prolonged wait for emergency services, which they accused the police of delaying.

Testimony later complained about the small number of black policemen on the New Castle police force and claimed that racial discrimination in New Castle's police department pervaded its highest ranks. Lennie Payne, for example, explained that the physical altercation with police ensued after he swung at Police Chief Richard Hanna, who had recognized his face among the crowd and, determining him suspect, proceeded to search him for a gun without reasonable suspicion. ${ }^{67}$ Payne previously applied to the department, passed the New Castle Police Department's physical and written exams, but failed the oral exam conducted by Chief Hanna ${ }^{68}$ Out of the department's sixty-one officers,

\footnotetext{
65 "Black Modeling Program Slated: Human Relations Commission Endorses Police Cadet Corps," New Castle News, June 9, 1970; "Our Editorial Opinion: Black Leadership Must Be Supported," New Castle News, September 4, 1971; and Paul Ward, "BCC President Writes About Racism in the Community," September 4, 1971.

${ }^{66}$ Guthery and Montgomery, interview.

${ }^{67}$ Manna, "Quick Chain of Events Brings Confusion: 'Every Available Man' Called Out," November 2, 1970.

${ }^{68}$ Matis, "Shooting Touches Off Violence," continued as, "Shooting Starts Violence," November 2, 1970. Though failure of the oral examination is sufficient reason for rejecting applicants to the police force, the assessment functioned in a fashion similar to
} 
only two were black, substantiating insistent claims by members of the black community that they did not receive "equal treatment" in hiring.

Meanwhile, the city's white police force upheld a façade of justice while policing the boundaries demarcating black space and defining the acceptable uses of violence. Warren Taylor, 19, Payne, 21, and Zollie Talley, Mitchell's 24-year-old brother-in-law, were charged with rioting, disorderly conduct, and obstructing police officers; Talley was also charged with assault with intent to kill and aggravated assault and battery. ${ }^{69}$ Though Payne accused Chief Hanna in testimony of profiling and unjustifiably searching him after wrongfully rejecting his application to the department, and though witnesses accused Lieutenant Dan Malley of instigating the event by pushing junior officers into the growing crowd of black bystanders while screaming "get them, get them," neither received any charges or departmental reprimand. ${ }^{70}$ Indeed, state police arriving after the fact defended and praised both men for not having employed deadly force ${ }^{71}$ The most critical white residents lamented in submissions to the News the lack of "dead rioters" while most praised the department's courage and dedication to maintaining "law and order" in the city. ${ }^{72}$ Divergent responses to the use of violence by members of the black community and police—seen in the charges

disenfranchising mechanisms like literacy tests used to control and oppress Southern black voters.

${ }^{69}$ Mike Matis, "Shooting Touches Off Violence," "Shooting Starts Violence," New Castle News, November 2, 1970.

70 "BCC Hears Eye Witness," New Castle News, November 2, 1970; "Lot Happened in A Short Time," New Castle News, November 23, 1970; and Robbins, "Acquitted on Other Charges: Payne Found Guilty of Riot," March 2, 1971.

71 "Lot Happened in A Short Time," New Castle News, November 23, 1970.

${ }^{72} \mathrm{Ibid}$. Elizabeth Kai Hinton illustrates how evolving political currents-specifically a conservative shift in Democratic and Republican party platforms that drew both toward espousing the primacy of retaining "law and order"_-justified changes in public policy and exponential increases in local, state, and federal spending on police departments across the country. Though police almost invariably received government sanction in cases of questionable action, Hinton explains that the spending increase beginning in the 1960s climaxed during the Reagan Administration's War On Drugs. Contemporary transformations of comparable racially-targeted state-sanctioned violence include hyper-incarceration and unbridled violence by uniformed officers of the law against people of color. Public sentiment supporting almost exclusively white police forces, despite their role in acting injustice upon groups of citizens, was fostered by daily navigation through primarily segregated white spaces, daily interactions with predominantly white social circles, and daily consumption of news and media mandating unquestioned support for defenders of the color line in their honorable portrayals and ostracizing the critical, particularly in the realm of political conversation and representation. 
against Taylor, Payne, and Talley, and the downplay of questionable provocations by Chief Hanna and Lieutenant O'Malley-communicated the acceptable use (and users) of violence and cemented what purposes it satisfied in maintaining social order and the racial status quo in New Castle. Only the latter possessed the ability to navigate between dualidentities as members of New Castle's white community and representatives of the law and state power. ${ }^{73}$

Mirroring restrictions on housing availability and social mobility, discriminatory hiring practices restricted employment opportunity, maintaining a hierarchy resembling that enforced by the police. Strategies involved repeated circumvention, or "the runaround," as Ward described it, resulting in significant occupational segmentation that placed black workers in the lowest-paying, most dangerous jobs. They also created barriers to entry for blacks seeking union membership or access to training programs. ${ }^{74}$ "I left for one year" to go to school "in Pittsburgh for architecture and design," Montgomery added his own experiences with discriminatory hiring practices, "and came back here and tried to get into...Rockwell. They told me no, you can't get into the office but you can work in the plant." Montgomery recalled that when he "came back... and got a job...they burned a cross at midnight." ${ }^{75}$ Control over hiring and terroristic uses of violence delimited what opportunities education and training might entail for black trades-workers.

Manufacturing and heavy industry employed a majority of residents in New Castle throughout the twentieth century; Mooney described downtown New Castle in 1970 as "bustling" and home to "a lot of heavy industry." ${ }^{76}$ Home of two Rockwell plants that employed

\footnotetext{
${ }^{73}$ For detailed investigation of urban policing in the twentieth century, specifically the use of violence (in many forms) for the maintenance of social order, see, Didier Fassin, Enforcing Order: An Ethnography of Urban Policing (Malden, MA; Cambridge: Polity Press, 2013); Van Cleve, Crook County.

74 "Housing Ceremony Picketed: Black Citizen's Protest Hiring," New Castle News, June 2, 1970. Employment and economic access provided black laborers a sense of self-pride. Employment by Rockwell, Montgomery explained, "made you ... an outstanding citizen. I'd know everything in my house was brand new ... I had a nice car ... I was doing big things." Guthery and Montgomery, interview.

${ }^{75}$ Guthery and Montgomery, interview.

${ }^{76}$ Over 52\% of employment opportunities in Lawrence County, of which New Castle is the seat, were in manufacturing and heavy industry in 1970. U.S. Census Bureau, Lawrence County Fact Book, 1970. Accessed December 22, 2017 at New Castle Public Library. New Castle has boasted nicknames like "hot dog capital of the world," and the "fireworks capital of America." Though the former possessed little significance beyond the region, the city was the local headquarters for two international fireworks producers, S. Vitale Pyrotechnic Industries, Inc. (Pyrotecnico), and Zambelli
} 
over three thousand people each, a Shenango Pottery, Mesta Engineering, and several steel and tin manufacturers, most of New Castle's employment opportunities, especially for minorities and immigrants of the lower and working classes, were industrial in nature, and employers hired poor and ethnic-whites at the discrimination of black workers. ${ }^{77}$ Despite completing trade-specific certification programs like those sponsored by Operation Dig of the Pittsburgh Construction Coalition, which sought placement for recently certified black tradesmen on federally-funded projects, or, as in Ronald Mitchell's case, receiving certification in carpentry from the Army, employers constantly evaded or deflected the attempts of black tradesmen seeking employment. ${ }^{78}$ At a BCC picket protest against the denial of work to black tradesmen on the Riverside Housing Project in the summer preceding his murder, Mitchell explained he was told he "could not speak with anyone" regarding employment-an injunction familiar to tradesmen of color. These and similar experiences conveyed to black tradesmen the uselessness of their certification and skill in the eyes of white employers. ${ }^{79}$

Occupational segmentation was only one method for maintaining black subordination in the workforce. White leadership also excluded black workers from union membership, barring their entry into numerous "skilled" trades like bricklaying, carpentry, and painting, and monopolizing the power of collective bargaining. ${ }^{80}$ News writer Ralph

Internationale. See, "New Castle, Pennsylvania - Our History,"

http://www.newcastlepa.org/index.html. Mooney, interview.

${ }^{77}$ Ward elaborated on the inequality; his father and other black residents were unable to find employment except at a blast furnace. Chemical exposure to toxins proved fatal to many and claimed Ward's father before the age of 50. "You couldn't get a job as a bricklayer" or any of what were considered skilled trades at the time, Ward recalled, "you were going to be by the blast furnaces." Ward, interview; Gatewood, interview. New Castle News, "Housing Ceremony Picketed: Black Citizen's Protest Hiring," June 2, 1970. Gatewood added that Johnson Bronze used to bring in workers from neighboring Jackson Knolls, the northern segment of Mt. Jackson about ten miles southwest, to fill the mills despite the presence of black male workers needing jobs. Clarence Ward, Paul Ward and Naomi Gatewood's late father, trained them, and the company paid for their housing, according to Gatewood's recollection. For more on defining "whiteness" social and legally, see Haney-Lopez, White by Law.

${ }^{78}$ John K. Manna, "BCC Plans for Meeting with Building Tradesmen," New Castle News, July 24, 1970.

79 "Housing Ceremony Picketed: Black Citizen's Protest Hiring," New Castle News, June 2, 1970.

${ }^{80}$ Ward, interview; "Housing Ceremony Picketed: Black Citizen's Protest Hiring," New Castle News, June 2, 1970; "Reasoning Together," New Castle News, June 3, 1970; "BCC Plans New Action on Unions," New Castle News, August 21, 1970; and, 
Deams despaired in 1970 that despite the decade being focused on training African Americans, they still experienced almost "twice the amount of unemployment as any other group." ${ }^{11}$ The National Planning Association, responsible for evaluating and recommending improvements to pertinent policy issues, identified the "discrimination against...racial groups practiced by some employers and in some cases by unions" as one of the most significant causes, to which they suggested "public education" for black tradesmen on their right to work, and charged unions to "use these workers" as a step towards resolution. ${ }^{82}$ David Crunkleton, Vice President of the BCC in 1970, also stressed the value of education, but noted that "courses in apprenticeship training were to be offered at the Vo-Tech school but were dropped because the teachers were members of the trade unions and too many blacks had enrolled." 83

Gatewood explained that black women "didn't have nobody to back us up because they wouldn't hire blacks." To discourage black women from seeking gainful employment, Gatewood remembered teachers "told all the black people to take home economics because...you're not to get no job typing, shorthand, or nothing." Gatewood recalled that white teachers expected black students, especially women and girls, to "be in somebody's kitchen, cooking or something." "That high school," she concluded laughing, "oh-ho-ho, Lord, very prejudiced." 84 Gatewood added that while applying to work at Bell Telephone alongside a white female counterpart following graduation from high school in January 1946, the woman receiving applications:

\footnotetext{
"Meeting Revealed by Ward," New Castle News, August 29, 1970. Unions practiced varying levels of discrimination and exclusion, and union actions never represented the positions of all members. Continued investigation is needed to determine the relationship between specific ethnic groups and historic trade specializations in the region, the extent to which ethnic majorities within particular unions influenced discriminatory and exclusionary practice and policy, and the impact of union nondiscrimination and inclusion for varying skilled black laborers.

${ }^{81}$ Ralph C. Deams, "Unemployment in Recessions," New Castle News, December 23, 1970.

82 Roscoe Drummond, "Unemployment and Prosperity," New Castle News, April 5, 1961

83 "Housing Ceremony Picketed - Black Citizens Protest Hiring," New Castle News, June 2, 1970.

${ }^{84}$ Gatewood, interview.
} 
tore it up right in front of me. She didn't care. She...tore it up right in front of me...didn't make no bones about it. She didn't say, you know...turn back and, and I'm going to tear it up. You know, nothing like that...That right there let me know...The whites were here and the blacks were there. We knew we were separated. We knew that. ${ }^{85}$

Colorism determined which, if any, black women found employment. "Betty Gunn...was really light," Gatewood recounted, and "got hired as the secretary, but she had to be near white looking." At New Castle Dry Goods, "the man said they would hire us," referring to black women, "but we'd have to be almost white-looking, not black like I am, no way they would hire you." "If you were light and everything, whatnot, they'd hire you. 186

Resistance by New Castle's black community to diverse and evolving forms of racially discriminatory and segregating practices across the twentieth century demonstrates that spaces between urban metropoles and rural sundown towns experienced manifestations of, and transformations in, racially discriminatory, exclusionary, and oppressive policies and practices encountered at both historiographical extremes in response to changing social, economic, and political conditions. Despite the presence of several organizations addressing unique concerns for specific groups within the black community, a shared ideologyfostered and strengthened by relation through the local branch of the NAACP, New Castle's exemplar national organization-provided a platform upon which groups collaborated toward establishing a network of opportunities and resources for community members, regardless of specific group membership. That community resisted throughout evolving conditions and circumstances by blending urban organizational principles with rural operational philosophy-bureaucratic and structural bodies collaborated in developing community-wide networks of opportunity and support regardless of group membership. ${ }^{87}$

\footnotetext{
${ }^{85}$ Ibid.

${ }^{86}$ Ibid.

${ }^{87}$ After elaborating briefly on the various positions comprising the Black Concerned Citizen's executive body, Gatewood explained the intentionality behind that name: "with our name being, Black Concerned Citizens, we would hold some weight" and chosen representatives "wouldn't have anything to worry about" (emphasis added by this author). In describing groundwork conducted by the BCC, Gatewood described a collaborative effort to find employment opportunities and disseminate them among blacks in need. "We had different people out in the field," she explained; some checked the post office, and others different places. She continued, "[M] aybe you're on this side
} 
Acknowledging some successes, it is difficult to overestimate the presence of overarching systems of structural inequality in framing daily life for people of color living in New Castle. ${ }^{88}$ Multimodal social, economic, and political violence in defense of white social, economic, and political interests inhered purposes comparable to sumptuary codes that fixed social stratification in the Jim Crow South, sharecropping and tenant-leasing systems that retained economic dependence following the abolition of slavery, and disenfranchisement or deterrence that limited the electoral power of the black vote into the mid-twentieth century. ${ }^{89}$ In

of town trying to do something at this place, maybe you went to the courthouse, maybe I went to City Council, maybe I went to the hospital ... because maybe I can do something you can't do." In describing the working relationship between local organizations like the Black Concerned Citizens and the coexisting national bodies, namely the NAACP, whose structure the BCC mirrors, Gatewood noted humorously that "just about the same people [in the BCC] was in the NAACP ... [W] didn't try to knock one another down. We tried to work together." Gatewood, interview.

${ }^{88}$ The consequences of multigenerational racisms and discriminatory practices persist today and can be measured across multiple dimensions. Geographic space remains predominantly segregated, with residents of color comprising most project-housing constituents. Unemployment among black residents remains disproportionately higher than white residents. Residual effects of earlier discrimination in housing and employment emerge from data on the number of black residents unemployed or living below the poverty line. From data collected in 2015, 22.6\% of all New Castle residents living below the poverty line are African American, despite comprising only $11.8 \%$ of the total population. The median income for historically black census tracts ranges from $\$ 11,250$ to $\$ 21,136$, while incomes in historically white census tracts surrounding the city core range from $\$ 38,750$ to $\$ 53,691$. This data was compiled by DATA USA, a project begun in 2014 under Cesar Hidalgo, professor at the MIT Media Lab and Director of Macro Connections, with the collaboration of several organizations, including Deloitte and Datawheel. See, https://datausa.io/profile/geo/new-castlepa/\#housing. Though New Castle's populations identifying as "White alone" $(13,786)$ and "Black alone" $(1,558)$ graduate high school or higher at comparable levels $(11,976$ / 86.9\%, and 1,373 / 88.1\%, respectively), attainment of a Bachelor's degree or higher differs widely between the groups. While $16.3 \%$ of the population identifying as "White alone" $(2,226)$ reported attaining a Bachelor's degree or higher, only $4.2 \%$ of the population identifying as "Black alone" (66) reported doing so. See, American Community Survey (2012-2016 Estimates): S1501 Educational Attainment, (Washington: U.S. Census Bureau, accessed online).

New Castle only recently (2002) began developing formerly cleared properties near the city-center into parks and other cultural attractions; those in Mitchell's former neighborhood remain abandoned and falling into disrepair or are replaced by housing projects or industrial manufactures.

${ }^{89}$ Most popular in the early twentieth century, the declining acceptability of cross burning as a form of racial intimidation - the combined outcome of a plethora of national and global factors-primed an environ welcoming to increased racial violence by police forces already historically rooted in the restriction and suppression of blacks. Gatewood, interview. 
response to an inquiry regarding the prevalence of cross-burnings in New Castle as means of racial intimidation, Gatewood explained that whites used "the cross more than anything," though extensive reports of racist abuses of power by police challenge the former practice's predominance. Montgomery added the inequitable outcomes of such violence against people of color. "It was happening every day...Y You'd see two people fighting and...the only one who is going to jail is the black person." Actors introduced race-based policies and practices in New Castle influenced and shaped by the city's unique history. Denise Guthery and Melvin Montgomery both collaborated in explaining how financiers stalled the approval of credit to a wealthy black dentist to defend the racial homogeneity of neighborhoods outside the city's core and ascending the surrounding hills. By 1970 a declining steel town but with a history dating to the U.S. frontier in 1798, forms of racism reflected the shaping of a fluctuating and changing economy and population under the influence of national and international circumstances and developments. The mistreatment of black residents by whites, especially the police, reified that city's racial hierarchy, long entrenched in cultural fixtures like minstrel shows and later lawn ornaments ordering social space. ${ }^{90}$ In seeking to reconcile the racism her father displayed in some contexts and settings, Guthery explained "I think everybody needs to be a bully in some way. You know, when you're growing up you need to have someone that you can bully that you can feel like you're better than, and sadly, that goes with the color of skin."91 Prevarication, occupational segmentation, prohibition from unions, and canceled training programs obstructed any potential for upward mobility sought through industrial employment. Zoning ordinances, urban development schemes, and

\footnotetext{
${ }^{90}$ Beyond the minstrel shows popular in the early twentieth century and racist lawn ornaments into the following decades, interviewee accounts include narratives of police mishandling of individuals with mental illnesses, abusive behavior and language toward black children, overuse of clubs in suppressing conflict, and racial "onesidedness," as one interviewee described what others called a "dual system of justice." When asked if the New Castle Police Department remained disproportionately white, Montgomery responded, "oh hell, yes, man, to this day ... They're the same way. They haven't changed. They're all white. There are no blacks," adding "they'd call you a 'nigger' too." "They never arrested them white kids ... They called me a nigger and they put me in the paper but they never said a thing" about white perpetrator. "They always, always, went for the black guy." Montgomery lamented how little has changed, as "police didn't arrest no damn body" in response to his daughter's murder in 2000. "They just brushed it under the rug," he lamented, "they've been brushing shit under the rug for years." Guthery and Montgomery, interview.

${ }^{91}$ Guthery and Montgomery, interview.
} 
The Graduate History Review 9, no. 1 (2020)

racially discriminatory housing policy limited the domicile available to black residents.

\section{"Where Do We Go From Here?": Historical Narrative and Public Memory $^{92}$}

Martin Luther King, Jr. recognized independently that which the National Advisory Commission on Civil Disorders recognized after over six months of research conducted by hundreds of individuals across the country. Where the Kerner Commission feared the further devolution of the United States into "two societies" both "separate and unequal," King recognized the historical impossibility and unsustainability of this outcome and concluded in his title that extant options included "chaos or community." The use of King's question in the heading of this analysis's conclusion seeks to revisit that question, "Where do we go from here?" The conversation surrounding historically discriminated and segregated communities of color necessarily requires a consideration of how much change has occurred since his assassination fifty years ago. A speech given by the president of the University of Cincinnati's Alpha Phi Alpha fraternity, James Lacy, at an event commemorating King's life and legacy on the 50th anniversary of his assassination at the city's National Underground Railroad Freedom Center, reckoned with the problematic dichotomy and questioned if "chaos" and "community" were mutually exclusive, and if restoring and emphasizing community cannot function as one means of disrupting the systems maintaining and perpetuating structures and systems of inequality. Perhaps the single greatest act of violence is erasure from memory. ${ }^{93}$ Based on the oral interviews conducted between 2016 and 2018 for this research, it was found that many of New Castle's residents cannot recall any detail about Mitchell's murder or the violent community responses that induced a three-day State-of-Emergency. The informative power of this historical moment is silenced; past generations' racially discriminatory and racist practices, and their residual consequences and contemporary forms, are disclaimed

\footnotetext{
${ }^{92}$ See Martin Luther King, Jr., Where Do We Do From Here: Chaos or Community? (Boston: Beacon Press, 1968).

${ }^{93}$ Trouillot illustrates how silences created at fact identification, creation, archiving, and recall silenced the memorialization of Colonel Jean-Baptiste Sans Souci by his assassin-Haiti's first King, Henry Christophe I-by constructing a narrative in which Christophe's decision to name the building erected at the site of Sans Souci's assassination after the Colonel is construed as an emulation of the earlier-named palace of Prussia's Frederick the Great, denying the possibility of Christophe memorializing or silencing Sans Souci's existence, replacing the man with the building and place.
} 
in their absence. These silences are "less visible than gunfire, class property, or political crusades," or an evening of vandalism and firebombing, but "are no less powerful." 94 Community memory gauged by public outreach revealed incomplete, if existent, awareness of the incident or vague recollection framed by themes of conflict and violence. ${ }^{95}$ Some interpretations reduced the importance of the perspectives sought by this author and offered alternatives that marginalized discrimination extant during the period of investigation or equated types of violence by actors occupying vastly different social, economic, and political positions. ${ }^{96}$ These responses often emphasized "good times growing up in New Castle," described by Otie Carmody as "a great place in the 1950s" compared to today, or maintained the "good and bad on both sides" raised by Florence Bruno Richardson. Specifically, Carmody reduces the importance of the subject of inquiry

94 Trouillot, Silencing the Past, xviii.

${ }^{95}$ Alex Tabor, "Fine People of New Castle, I need YOUR Help," Facebook, January 31, 2018, https://www.facebook.com/groups/newcastlepa/permalink/10155566066776051/. Carol Hamed regretted, "I wish I could help you with this project ... I would have been 18 at the time and have no memory of this. I asked my husband who lived just a few blocks from this area ... he would have been 19 years old. He cannot remember this murder." Robin Masi, who explained she "was only in $2^{\text {nd }}$ grade" and lived "on the upper east side," had no recollection. Kara Melissa Stevenson Stinnett was "4 or 5 at the time" and remembered only her "father being upset and not allowing my mom to take us to that area to shop." Though remembering with notable detail the violence between black and white students while first transitioning from a Catholic school to New Castle Area High School her sophomore year, Marilou Tomski Zaverl did not recall Mitchell's shooting or subsequent responses; both Zaverl and Cindy Crognale describe violent interaction between black and white students as "riots."

The inquiry stirred incensed responses from others. Susan Delores rebuked some of the outreach's wording, writing "I don't know where you['re] getting antagonistic police force unless you were there." She noted fear of when her father "had to go out in riot gear," and that caused by anonymous callers' threats to harm her family. Given that all experiences are unique and valid to those experiencing or receiving them, Susan Delores's response provides one gauge for the sensitivity of some members of the white community to precarious relationships between New Castle whites and people of color (emphasis added by author, full Post text appended).

${ }^{96}$ Dissonance to contentions within local history, imbued within a seemingly innocuous comment disconnected from the framed inquiry, is one means of deflecting, obscuring, and redirecting efforts to incorporate that suppressed history into broader, general civic discourse. As surely as intentions and motivations varied widely between individual actors in the plethora of tumultuous conflicts in mid-century New Castle, Carmody and Richardson illustrate additional means of coping with complex, complicated, and contentious aspects of local history that run counter to the extant positive narratives responsible for binding New Castle's white community. Alex Tabor, "Fine People of New Castle." 
by shifting the topic and ignoring that which is posited, and Richardson acknowledges contention, but damns individuals on both sides, conceptualizing the source of conflict as individual action, behavior, and consequence, rather than a product of structural, systemic inequalities.

The contemporary silences surrounding Mitchell's murder and its context within New Castle's freedom struggle-whether neglected, overlooked, or suppressed by local institutions and organizations - and the minimal account of black history in the city's records, render current narratives of the city's history, a pillar of local and regional identity, incomplete. Members of the New Castle Police Department and New Castle Area School District School Board employed what interviewees called "the run-around" upon the author's request of certain documents and information, and several white residents contested and denied the realities of black contributors and interviewees. When discussing the extent to which this research involved several public institutions in New Castle, Gatewood laughed, explaining: "They're not going to tell you nothing." Describing most as "very prejudiced," she added that "the people that would know about that murder here in New Castle, those are the ones you're not going to get no information from." ${ }^{17}$ The dynamics inherent to contests over social, economic, and political resources in the economically fluctuating, semi-urban, regionally agricultural city are critical to understanding its history and at least some of the forces shaping its evolution, and that of similar spaces in-between.

Indeed, Mitchell's murder did not independently incite the evening of vandalism, physical conflict with police, or subsequent firebombing. A matrix of racisms and discriminatory practices occurring and compounding across generations framed black interpretations of Mitchell's murder, many of which manifested at the scene in the delay of emergency services, racist police actions, and ignorance of the plights of New Castle's black citizens. ${ }^{98}$ The denial and elision of this narrative

\footnotetext{
${ }^{97}$ Gatewood, interview.

${ }^{98}$ Guthery and Montgomery corroborate brief references to fights between black and white students in the News in 1968-1969 while Mitchell served as a carpenter in the Army in Vietnam, providing a modicum of evidence that tension between members of New Castle's black and white communities increasingly took violent form throughout the 1960s. Ignorance to the needs and interests of black citizens repeatedly demonstrated throughout the decade, compounded especially by events occurring nationally, namely the assassination of numerous black and white civil rights leaders, spurred a militant ideological outgrowth within the black community. Montgomery explained that The assassinations of Kennedy and MLK, Jr., "kind of made me a rebel ... I cried when he got shot." "It kind of made me more militant. I don't remember being militant as a little kid." "But ... when Kennedy got shot, then his brother got shot
} 
from New Castle's public memory and civic discourse, whether neglected, overlooked, or suppressed, renders many narratives of the city's history - a core dimension of civic identity — incomplete and thus denies to the enduring struggle for equitable and fair treatment historical influence.

As systematic control of housing availability, employment opportunity, and educational access circumscribed life opportunities for people of color across every dimension, similar control over public memory - the narratives used in formulating individual and community identities - maintains similar limits upon civic awareness and obligation. ${ }^{99}$ In the same fashion that isolation from federal loan and subsidy decimated opportunities for black families to accrue a modicum of the generational wealth amassed by white families throughout the mid-twentieth century, the silencing of New Castle's freedom struggle from the city's historical narrative, and from that city's civic discourse, similarly obstructs the addressing of inequitable systems and redressing of past violations responsible for the disproportionate disadvantages experienced by members of the city's communities of color. The consequences of racially discriminatory policy dictating the use and purpose of residential space and workplace organization, and of racially segregating practices framing relations between black and white citizens, remain discernable in their influence on the present and future.

Despite obstructions and barriers to access in fair and equitable housing, education, and employment, the black community organized to collect and share resources like employment opportunities, protest

and then Martin Luther King ... I was militant as all get-up. I ain't going to tell no lie. That's all I wanted to do, was fight." Guthery and Montgomery, interview.

${ }^{99}$ In his analysis of social movements, Aldon Morris applies Resource Mobilization

Theory to hypothesize various reasons for the successes or failures of social movements within the Modern Civil Rights Movement that he periodizes between 1954 and 1963. Beyond lacking sufficient resources_-as diverse as population size/human capital, consumer power/financial capital, social network connection or economic access/social capital, political affiliation, or control over narratives used in identity-formulation or community maintenance - the momentum unachieved also precluded the support from external groups necessary for sustained campaigns against inequitable systems, the notable exception being the black-led Pittsburgh Construction Coalition, which collaborated in educating black male laborers on their legal rights to employment on various jobs. Morris's application of Resource Mobilization Theory is applicable to intangible, sociocultural generational wealth expressed in ancestral or familial history in relation to mainstream society, sense of individual or group pride or sense of belonging derived from connection to and investment in reciprocating social order, and also individual and collective public memory. See Morris, Origins of the Civil Rights Movement, 275-90. 
discriminatory businesses and projects like the Riverside housing development, where black tradesmen were denied work despite the project's federal underwriting, and respond with violent resistance to violent racism. However, contemporary manifestations of social, economic, and political policies and practices experienced throughout the mid-twentieth century persist in legal precedent, sociocultural perceptions, and consumed imagery. ${ }^{100}$ Beyond disparities in accrued generational wealth, the scars of residential security maps and discriminatory housing policy mark urban spaces almost ubiquitously, including New Castle. ${ }^{101}$ Consequences of discriminatory hiring

\footnotetext{
${ }^{100}$ Haney-Lopez, White by Law and Bonilla-Silva, Racism Without Racists illustrate how historical and social perceptions of race and equality are embedded within daily consumption, discourse, and performance. Martin Luther King, Jr. noted the social and psychological consequences and implications of similar ritualized performances of "race" continuing nearly a century following emancipation. King specifically addressed the false superiority-inferiority complex often internalized but needing resisted by actors existing within a societal framework built upon white supremacy. See, Why We Can't Wait (New York: New American Library, 2000). Nicole Gonzales Van Cleve's Crook County: Racism and Injustice in America's Largest Criminal Court (Stanford, California: Stanford University Press, 2016) illustrates how racial (mis)perceptions and racial ideology are daily constructed, affirmed, and validated at the interaction levelas actors navigate unique and evolving contexts and spheres of social space-but also by contextual, sensory consumption.

${ }^{101}$ Some investigations emphasize economic disinvestment: Bruce Mitchell and Juan Franco, "HOLC 'redlining' maps: The persistent structure of segregation and economic inequality," National Community Reinvestment Coalition, March 20, 2018, https://ncrc.org/holc/; Mitchell, "Reversing the red lines: Disinvestment in America's cities," National Community Reinvestment Coalition, March 27, 2018, https://ncrc.org/reversing-the-red-lines-disinvestment-in-americas-cities/; Jesse Meisenhelter, "How 1930s discrimination shaped inequality in today's cities," National Community Reinvestment Coalition, March 27, 2018, https://ncrc.org/how-1930sdiscrimination-shaped-inequality-in-todays-cities/; Alana Semuels, "The Resurrection of America's Slums," The Atlantic, August 9, 2015, https://www.theatlantic.com/business/archive/2015/08/more-americans-are-living-inslums/400832/?fbclid=IwAR3Ws6Wr66HfAAXmXvA3g a1APr1ZIRyGNu5VQJ75Es hgDJs9csNArf6AyU\&utm campaign=theatlantic\&utm content $=5$ caa3 3 acfe $6 \mathrm{dfda} 0001 \mathrm{dc} 9 \mathrm{e} 59$ ta\&utm medium $=$ social\&utm sou rce=facebook; Adrian Florido, "Black, Latino Two-Parent Families Have Half The Wealth of White Single Parents," Codeswitch: Race and Identity, Remixed, National Public Radio, February 8, 2017, https://www.npr.org/sections/codeswitch/2017/02/08/514105689/black-latino-twoparent-families-have-half-the-wealth-of-white-singleparents?fbclid=IwAR0r1z6pvT87iMuF9KRA5jV5ajcW7JRFaccTqytCamoskxYWTQ4Kxfvxc0.

Others focus on environmental racism intertwined with discriminatory housing policy: Jonathan Lambert, "Study Finds Racial Gap Between Who Causes Air
} 
practices leave traces in schools with few black teachers and predominantly white police departments. ${ }^{102}$ The enduring consequences

Pollution and Who Breathes It," National Public Radio, March 11, 2019, https://www.npr.org/sections/health-shots/2019/03/11/702348935/study-finds-racialgap-between-who-causes-air-pollution-and-who-breathes-it?fbclid=IwAR0f96ZYkFIvz2s5Jgjw1DGNRah0VdTeO2CMpANovBQC8xBxwifMwgRunU. CityLab writer Tanvi Misra's April 10, 2019, article "From Gentrification to Decline: How Neighborhoods Really Change," highlights new and changing trends in concentrations of poverty and demographic distribution as consequence of discriminatory behavior. See, Tanvi Misra, "From Gentrification to Decline: How Neighborhoods Really Change," CityLab, April 10, 2019, https:/www.citylab.com/equity/2019/04/gentrifiedcities-neighborhood-change-displacement-povertydata/586840/?utm campaign=citylab-dailynewsletter\&utm medium $=$ email\&silverid $=\% 25 \% 25$ RECIPIENT_ID $\% 25 \% 25 \&$ utm so urce=newsletter.

The University of Richmond's Digital Scholarship Lab has produced three invaluable assemblages of data able to be analyzed graphically and visually with maps that illustrate significant changes in housing availability, distribution, and occupation over time and in response to changing racially discriminatory policies and practices. American Panorama: An Atlas of United States History serves as a hub at which several graphs and maps depicting historical change are accessible, among which Mapping Inequality: Redlining in New Deal America and Renewing Inequality: Urban Renewal, Family Displacements, and Race 1955-1966 can be found. See, https://dsl.richmond.edu/panorama/ (American Panorama), https://dsl.richmond.edu/panorama/redlining/\#loc $=3 / 36.74 /-96.86 \&$ opacity $=0.8$ (Mapping Inequality), and http://dsl.richmond.edu/panorama/renewal/\#view=0/0/1\&viz=cartogram (Renewing Inequality). Rothstein, The Color of Law.

102 The NAACP continues to enjoin the New Castle Area School District to hire more teachers and administrators of color in 2018. See, Debbie Wachter, "NAACP urges school district to recruit minorities," New Castle News, January 18, 2018, http://www.ncnewsonline.com/news/naacp-urges-school-district-to-recruitminorities/article 60043562-fbd8-11e7-88f5-e30668e3fe6c.html. U.S. Department of Justice, Bureau of Justice Statistics, Census of State and Local Law Enforcement Agencies, 2008, by Brian A. Reaves, Bulletin NCJ 233982, July 2011, http://www.bjs.gov/index.cfm?ty=pbdetail\&iid=2216; Mike Macaig, ed., Diversity on the Force: Where Police Don't Mirror Communities, Governing: The States and Localities, September, 2015, http://images.centerdigitaled.com/documents/policediversityreport.pdf; Clarence Edwards, "Race and the Police," National Policing Foundation, February 8, 2016, https://www.policefoundation.org/race-and-the-police/; Jeremy Ashkenas and Haeyoun Park, "The Race Gap in America's Police Departments," The New York Times, April 8, 2015, https://www.nytimes.com/interactive/2014/09/03/us/the-race-gap-in-americaspolicedepartments.html?mtrref=www.google.com\&gwh=2F6F843489403DC1470A0BA7A0 A3DC6A\&gwt=pay. Human Rights Watch, an international advocacy organization, has produced among the most extensive reports on systems protecting excessive and undue use of force by police and law enforcement, often fatally and almost invariably without 
of disproportionate criminal punishment, social and political discrimination, and the influence of changing social, economic, and political conditions mark communities of color. ${ }^{103}$ Classism and racism continue to intersect locally, regionally, and nationally to perpetuate inequality much alike caste systems. ${ }^{104}$

New Castle's expansion from a rural, frontier village to booming industrial steel town, and since into more uncertain economic territory, and the changing composition and size of its population, framed a context in which diverse groups competed for limited resources. The pale disposition of the city's historic officeholders was not produced by majoritarian politics alone, though the African American population historically comprised between ten and fifteen percent of the city's total population. Local social, economic, and political behavior, and respective means of acting on racist belief, never escaped the influences, limits, obligations, and obstructions of national and international scalesometimes embraced and mirrored, others spurned and resisted. ${ }^{105}$

consequence in the United States. Aside from investigating the judicial and political systems that protect officers and shield departments from oversight or consequence, the report details fourteen U.S. cities and appends relevant government documents. See, "Shielded from Justice: Police Brutality and Accountability in the United States," Human Rights Watch, July 1, 1998, www.hrw.org.

${ }^{103}$ Emily Badger, Claire Cain Miller, Adam Pearce, and Kevin Quealy, "Extensive Data Shows Punishing Reach of Racism for Black Boys," The New York Times, March 19, 2018, https://www.nytimes.com/interactive/2018/03/19/upshot/race-class-whiteand-black-men.html. The National Women's Law Center provides extensive data necessarily including the experiences of women of color, including Hispanic, Native, and black women. See, Race \& Gender Wage Gaps, National Women's Law Center, https://nwlc.org/issue/race-gender-wage-gaps/. Louis Menand, "The Color of Law," The New Yorker, July 1, 2013, https://www.newyorker.com/magazine/2013/07/08/thecolor-of-law. In an "Announcements" email by The Sentencing Project's Marc Mauer to subscribers titled "New Prison and Jail Population Figures Released by U.S.

Department of Justice," Mauer notes that though six states reduced their prison populations by over $30 \%$ in the last two decades, the U.S. remains the world leader in rates of incarceration and that racial disparities in women's incarceration, and women's incarceration generally, have increased dramatically, with black women incarcerated at $10.8 \%$ and Hispanic women at $8.4 \%$ the rate of white women. Marc Mauer, The Sentencing Project, e-mail message to author, April 25, 2019.

104 Alexander, The New Jim Crow; Blackmon, Slavery by Another Name; Subramanian Shankar, "Does America Have a Caste System?" CityLab, January 26, 2018, https://www.citylab.com/equity/2018/01/does-america-have-a-castesystem $/ 551591 /$ ?utm source $=$ atlfb.

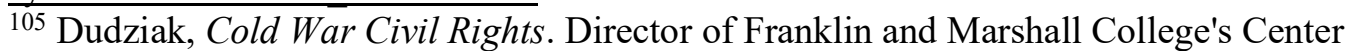
for Politics and Public Affairs, Terry Madonna, in a televised C-Span commentary titled "Political Dynamics of Pennsylvania" that aired November 1, 2018, noted that though the economy's influence on regional voting patterns is decreasing, economic 
A body of literature illustrates how changing social environments, fluctuating economic conditions, and volatile political balances interact within major urban cities to affect the lives of people of color. Corresponding dynamics in rural spaces receive increasing attention as investigations of the urban-suburban relationship incorporate broader regions. New Castle's local and regional history, social disposition, economic transformation, and political history defined the spectrum of permissible racist policies and practices throughout the twentieth century. Uniquely, New Castle and similar mid-sized cities, especially those experiencing significant change or transformation across the twentieth century, provide cases in which transforming policies and practices can be analyzed. ${ }^{106}$ New Castle's economic fluctuation provides an interesting case in which racist policies and practices evolve in response to changing economic conditions and weave through different fields of existence in response to diverse pressures. In places between major urban centers and rural counter-extremes like New Castle, varied and changing concepts of class coalesced with dynamic understandings of race and racism to inform policies and practices able to comfortably apply different dimensions of classism and racism under evolving circumstances. A greater understanding of relationships between external influences and local dynamics in places between population extremes supports ongoing research on contemporary manifestations of racism in policy and practice in the U. S.

\footnotetext{
improvement in the state falls short of national averages and stagnant local economies lacking jobs are spurring outmigration. Madonna explained that urban areas and "third class cities" leaned heavily democratic, and described rural, small towns, like "old mining and mill counties," as "republican havens." Washington Journal, "Terry Madonna on the Political Dynamics of Pennsylvania," C-Span, November 1, 2018, Pedro Echevarria.

${ }^{106}$ Pennsylvania owns eight of the United States' 769 cities with populations greater than 50,000 (1.04\%), in which reside 2,403,365 citizens. New Castle, however, falls among that state's additional 1,005 incorporated places with populations ranging from ten to over 44,000 - home to 5,608,476 of the states approximately 12.8 million. U.S. Census Bureau, Population Division, Annual Estimates of the Resident Population for Incorporated Places of 50,000 or More, Ranked by July 1, 2017 Population: April 1, 2010 to July 1, 2017, May, 2018, and, Annual Estimates of the Resident Population: April 1, 2010 to July 1, 2017, May, 2018.
} 
The Graduate History Review 9, no. 1 (2020)

\section{Appendix A: Social Media Outreach Targeted Facebook Inquiry (Text Only)}

Fine People of New Castle, I need YOUR help:

I am currently finishing my Master's degree in history at the University of Cincinnati, and in 2016 completed undergraduate studies at Slippery Rock University.

A project I began while a studying history at Slippery Rock that has now become my primary work focuses specifically on New Castle throughout the $20^{\text {th }}$ century, and though my research has been rewarding, no better sources exist than those who experienced the moment - thus why I reach out to you today.

Shortly after midnight on November $1^{\text {st }}, 1970$, a drive-by shooter killed Vietnam veteran Ronald Mitchell outside the Rainbow Gardens Bar on Long Avenue. Shortly after, a fight broke out between some bystanders and a questionably antagonistic police force. Though some vandalism occurred along Long Avenue that morning, the real damage remained unseen until that night, when firebombs on Long Avenue and Grant St. occupied firefighters until morning and provoked Mayor Carl A. Cialella to order a state of emergency for three days.

Though Ronald Mitchell's story is but one among many of a list of tragedies, his serves as a doorway into much broader conversations about race/racism in the $20^{\text {th }}$ century, but also about community, identity, and the struggle toward progress... even how we define "progress."

I am looking specifically for people who recall this moment in New Castle history: people for whom what I have very briefly summarized is recognizable or familiar, individuals present or aware of others present that evening, or those who recall the events broader reception within New Castle.

Beyond this specific event, I am also interested in people's individual experiences growing up in New Castle, particularly between the Great Depression and today. Personal and family stories, photographs/artifacts, and memories of New Castle's presence in 
Pennsylvania or its relation to national events are all enthusiastically encouraged and welcome.

If any of this connects with you and you feel compelled to share your experiences and stories, I am beyond appreciative of your time and willingness. Feel free to contact me on here with any unanswered questions, I can also provide further contact information at that time.

Looking forward to hearing your story,

All best,

Alex Tabor 
The Graduate History Review 9, no. 1 (2020)

\section{Appendix B: Insurance Redlining Map, New Castle City, Lawrence} County, Pennsylvania (1928)

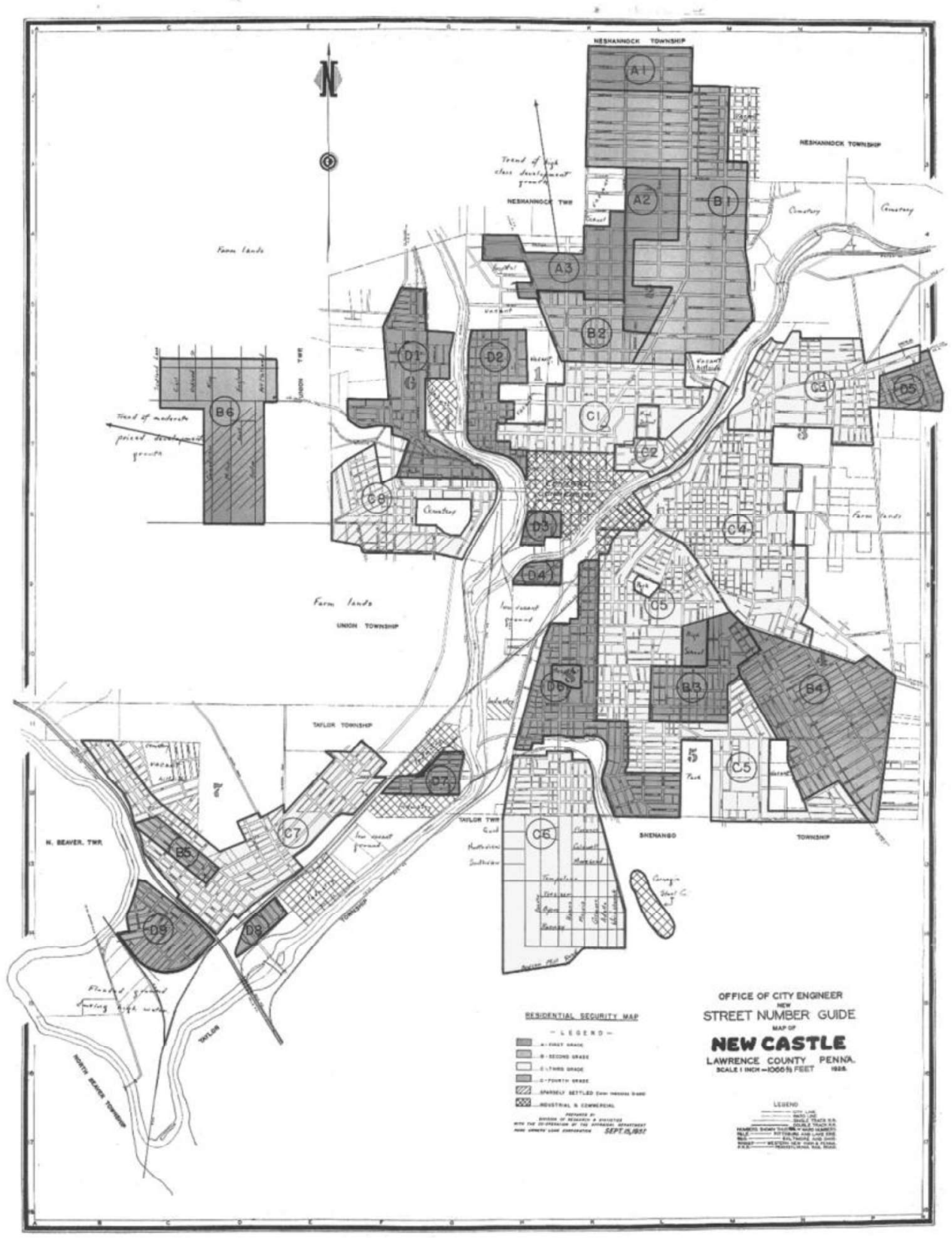

Figure 1: City of New Castle Office of the City Engineer, Street Number Guide Map of New Castle, Lawrence County, Penna., Division of Research \& Statistics with the cooperation of the Home Owners' Loan Corporation Appraisal Department, September $15,1937$. 


\section{Bibliography}

\section{Primary Sources}

\section{Government Reports}

Population Division, Bureau of the Census, United States. Annual Estimates of the Resident Population: April 1, 2010 to July 1, 2017. May 2018.

Population Division, Bureau of the Census, United States. Annual Estimates of the Resident Population for Incorporated Places of 50,000 or More, Ranked by July 1, 2017 Population: April 1, 2010 to July 1, 2017. May 2018.

Bureau of the Census, United States. 2013-2017 American Community Survey 5-Year Estimates. https://factfinder.census.gov/faces/tableservices/jsf/pages/produc tview.xhtml?src=CF.

Bureau of the Census, United States. Lawrence County Fact Book, 1970. Pittsburgh: Comprehensive Health Planning Association of Western Penna., Inc., 1970.

Johnson, Lyndon B. "The President's Address to the Nation on Civil Disorders." July 27, 1967. Online by Gerhard Peters and John T. Woolley, The American Presidency Project. http://www.presidency.ucsb.edu/ws/?pid=28368.

Johnson, Lyndon B. "Executive Order 11365-Establishing a National Advisory Commission on Civil Disorders." July 29, 1967. Online by Gerhard Peters and John T. Woolley, The American Presidency Project. http://www.presidency.ucsb.edu/ws/?pid=106100.

National Advisory Commission on Civil Disorders, Report of National Advisory Commission on Civil Disorders. Washington, United States: Kerner Commission, U.S. G.P.O., April 1968.

U.S. Department of Justice. Bureau of Justice Statistics. Census of State and Local Law Enforcement Agencies, 2008, by Brian A. Reaves. Bulletin NCJ 233982, July 2011, http://www.bjs.gov/index. cfm?ty=pbdetail\&iid $=2216$.

\section{Interviews by Author}

Gatewood, Naomi. December 30, 2017.

Guthery, Denise. December 21, 2017. 
The Graduate History Review 9, no. 1 (2020)

Mitchell, Jennie. September 20, 2014.

Montgomery, Melvin. December 21, 2017.

Mooney, Anna Mary. September 11, 2014.

Ward, Evelyn. September 19, 2014.

Ward, Paul V. September 19, 2014.

\section{Newspaper Articles}

Ashkenas, Jeremy and Haeyoun Park. "The Race Gap in America's Police Departments." The New York Times, April 8, 2015, https://www.nytimes.com/interactive/2014/09/03/us/the-racegap-in-americas-policedepartments.html?mtrref=www.google.com\&gwh=2F6F8434894 03DC1470A0BA7A0A3DC6A\&gwt=pay.

Badger, Emily, Claire Cain Miller, Adam Pearce, and Kevin Quealy. "Extensive Data Shows Punishing Reach of Racism for Black Boys." The New York Times, March 19, 2018, https://www.nytimes.com/interactive/2018/03/19/upshot/raceclass-white-and-black-men.html.

Burcham, David. "More than a century ago, steel was the rage," New Castle News, February 25, 2013.

Deams, Ralph C. "Unemployment in Recessions." New Castle News, December 23, 1970. Drummond, Roscoe. "Unemployment and Prosperity." New Castle News, April 5, 1961.

Florido, Adrian. "Black, Latino Two-Parent Families Have Half The Wealth of White Single Parents." Codeswitch: Race and Identity, Remixed, National Public Radio, February 8, 2017, https://www.npr.org/sections/codeswitch/2017/02/08/514105689 black-latino-two-parent-families-have-half-the-wealth-of-whitesingle-parents?fbclid=IwAR0r1z6pvT87iMuF9KRA5jV5ajcW7JRFaccTqytCamoskxYWTQ4Kxfvxc0.

Garcia, Dick. "Alternate Plan Offered Board by West Side." Continued as "Alternate Plan is

Offered." New Castle News, November 24, 1970.

Hassel, James E. "The People Write: Painters Union Explains Apprenticeship Program." New Castle News, September 18, 1971.

Kempster, Norman. "Real Estate: Government Planner Hits Zoning in Suburbs." New Castle News, September 4, 1971.

Kolasinksi, Len. "A Matter of Opinion: Their Goals Are the Same." New Castle News, June 6, 1970. 
Lambert, Jonathan. "Study Finds Racial Gap Between Who Causes Air Pollution and Who Breathes It." National Public Radio, March 11, 2019 , https://www.npr.org/sections/healthshots/2019/03/11/702348935/study-finds-racial-gap-betweenwho-causes-air-pollution-and-who-breathesit?fbclid=IwAR0f96ZYkFIvz2s5Jgjw1DGNRah0VdTeO2CMpANovBQC8xBxwifM wgRunU.

Linville, Susan. "1950s saw tide of downtown demolition start to roll in," New Castle News, May 27, 2017.

Manna, John K. "BCC Plans for Meeting with Building Tradesmen." New Castle News, July 24, 1970.

"'Quick Chain of Events Brings Confusion: Every Available Man' Called Out." New Castle News, November 2, 1970.

-Proposed Zoning Ordinance Scored by Seventh Warders." New Castle News, April 2, 1971.

"Redevelopment Brings Questions from People." New Castle News, January 28, 1972.

-'Instant Housing' Not Quick Here." Continued as, "'Instant Housing' In City Neither Quick, Nor Cheap." New Castle News, February 25, 1972.

"Fuller Headstart Program Urged by the Rev. Marks." New Castle News, April 7, 1972. Matis, Mike. "County Revises Planning for West Park Development" New Castle News, June 3, 1970.

"Shooting Touches Off Violence," continued as, "Shooting Starts Violence." New Castle News, November 2, 1970.

Meisenhelter, Jesse. "How 1930s discrimination shaped inequality in today's cities." National Community Reinvestment Coalition, March 27, 2018, https://ncrc.org/how-1930s-discriminationshaped-inequality-in-todays-cities/.

Menand, Louis. "The Color of Law," The New Yorker, July 1, 2013, https://www.newyorker.com/magazine/2013/07/08/the-color-oflaw.

Mihalcik, George. "Center Directors Quiz Razzano, George on Finances." New Castle News, August 27, 1969.

Mitchell, Bruce and Juan Franco. "HOLC 'redlining' maps: The persistent structure of segregation and economic inequality." National Community Reinvestment Coalition, March 20, 2018, https://ncrc.org/holc/. 
The Graduate History Review 9, no. 1 (2020)

Mitchell, Bruce. "Reversing the red lines: Disinvestment in America's cities." National Community Reinvestment Coalition, March 27, 2018, https://ncrc.org/reversing-the-red-lines-disinvestment-inamericas-cities/.

Misra, Tanvi. "From Gentrification to Decline: How Neighborhoods Really Change." CityLab, April 10, 2019, https://www.citylab.com/equity/2019/04/gentrified-citiesneighborhood-change-displacement-povertydata/586840/?utm campaign $=$ citylab-dailynewsletter\&utm medium $=$ email\&silverid $=\% 25 \% 25$ RECIPIENT ID $\% 25 \% 25 \&$ utm source $=$ newsletter.

Pezzuto, Lugene. "Former Rockwell Springs Division Employees Reunited, Reminisce." New Castle News, August 7, 2017.

Robbins, Dick (Richard). "Acquitted on Other Charges: Payne Found Guilty of Riot." New Castle News, March 2, 1971.

Robbins, Richard. "HRC-Realtor Meeting Delayed: Mailing Foulup Blamed." New Castle News, January 5, 1973.

Rombach, Rich. "Firebombs Riddle City Last Night" New Castle News, November 2, 1970.

-Housing Problem Discussed." New Castle News, October 13, 1971.

"Housing Problem Unsolved." Continued as, "Housing Problem Discussed." New Castle News, October 15, 1971.

"West Side Housing Problem Still." Continued as, "West Side Housing Aired." New Castle News, March 24, 1972.

"Council to View Public Housing." New Castle News, April 26, 1972.

Semuels, Alana. "The Resurrection of America's Slums." The Atlantic, August 9 , 2015 , https://www.theatlantic.com/business/archive/2015/08/moreamericans-are-living-inslums/400832/?fbclid=IwAR3Ws6Wr66HfAAXmXvA3g_a1AP r1ZIRyGNu5VQJ75EshgDJs9csNArf6AyU\&utm campaign=the z atlantic\&utm content $=5$ caa3acfe 6 dfda0001dc9e 59 ta\&utm med ium $=$ social\&utm source=facebook.

Shankar, Subramanian. "Does America Have a Caste System?" CityLab, January 26, 2018, https://www.citylab.com/equity/2018/01/does-

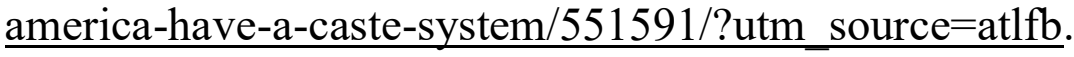


Treesh, Frederick H. "Hope for the Cities: Planned Use of Land Vital to Future." New Castle News, June 3, 1970.

Wachter, Debbie. "NAACP urges school district to recruit minorities." New Castle News, January 18, 2018, http://www.ncnewsonline.com/news/naacp-urges-school-districtto-recruit-minorities/article 60043562-fbd8-11e7-88f5e30668e3fe6c.html.

"Sarandrea leaves New Castle superintendent post with \$210,000 buyout." New Castle News, July 31, 2018. http://www.ncnewsonline.com/news/sarandrea-leaves-newcastle-superintendent-post-with-buyout/article 55601af8-946311e8-a9a6-87bdfd2ae022.html.

Ward, Paul V. "BCC Expresses Opinion on Integration Plan." New Castle News, November 18, 1970.

"BCC President Writes About Racism in the Community." New Castle News, September 4, 1971.

\section{Newspaper Articles (Author Not Cited)}

The New Castle Herald, "New Castle Tin Mill Plan Banner Night: Employees and Families to $\mathrm{Be}$ Entertained at Carnegie Auditorium Saturday Evening." March 4, 1920.

New Castle News. "Mayor Bans Fireworks, Would Give Aliens Chance to Do Damage: Says that Order Tends to Safeguard Property from Alien Enemies." May 11, 1917.

"Hallowe'en Celebration in Ellwood Big Success." November 2, 1926.

"Housing Ceremony Picketed: Black Citizens Protest Hiring." June 2, 1970.

"Building Trades Council is Lauded for Riverside Housing Project." June 3, 1970.

-County Protests Mandated Programs." June 3, 1970.

"Reasoning Together." June 3, 1970.

-"State Police Double Helicopter Fleet." June 6, 1970.

"BCC to Meet to Discuss Craft Unions." June 8, 1970.

"City Schools Desegregation Conferees Named." June 9, 1970.

-Black Modeling Program Slated: Human Relations

Commission Endorses Police Cadet Corps." June 9, 1970.

"Ostrowski To Head Integration Group." July 24, 1970. 
The Graduate History Review 9, no. 1 (2020)

"BCC Plans New Action on Unions." August 21, 1970.

"Meeting Revealed by Ward." August 29, 1970.

"BCC Hears Eye Witness." November 2, 1970.

-Officials Survey Situation." November 2, 1970.

_"Calm Heads Must Prevail." November 2, 1970.

"Two Parks Approved in Union." November 2, 1970.

- Curfew Holds in the City." November 3, 1970.

"Firemen Find Night Quiet." November 3, 1970.

"South Side Business May Close." November 3, 1970.

"Lot Happened in A Short Time." November 23, 1970.

"Alternate Plan is Offered." November 24, 1970.

"Census Figures: Youth Shows Below National Average Here."

March 2, 1971.

-"Concern Expressed by PAL." March 31, 1971.

-"Council Views Housing Tonight." September 28, 1971.

"Township May Lose Funds." May 10, 1971.

"Black Leadership Must Be Supported." September 4, 1971.

"Application for City Renewal Grant OKd." September 28, 1971.

"Progressive League Hears Barnes Speak." September 28, 1971. "Progressive Action." October 13, 1971.

"25 Black Leaders Organize." January 14, 1972.

"PAC Will Explain to PAL." January 21, 1972.

"PAL Asks Seat on Commission." February 16, 1972.

-"Council, PAL to Meet." March 28, 1972.

"Concern Expressed by PAL." March 31, 1972.

-"The People Write: Fair Housing Sought." April 28, 1972.

"BCC Seeks Training Program." May 8, 1972.

"Black Legislators to Fight Anti-Bus Bill." May 10, 1972

"Home Town Plan Asked by Group." May 11, 1972.

"PAL Plans Banquet." September 5, 1972.

"City HRC to Investigate PAL Discrimination Charge."

December 5, 1972.

"Sickle Cell Society to Organize." December 6, 1972.

"CHARGE Official Raps Policies of Board President."

December 22, 1972.

"HRC Withholds Comment on Plan for Desegregation." June 4, 1974. 
"The School Solution." March 9, 1974.

"Urban-Suburban Busing?" June 4, 1974.

\section{Secondary Sources}

Alexander, Michelle. The New Jim Crow: Mass Incarceration in the Age of Colorblindness. New York: The New Press, 2012.

Allen, James, ed., Hilton Als, Congressman John Lewis, and Leon F. Litwack, Without Sanctuary: Lynching Photography in America. Santa Fe, NM: Twin Palms Publishers, 2000.

Bell, Derek. Faces at the Bottom of the Well: The Permanence of Racism. New York: Basic Books, 1992.

Black, Les, and John Solomos, eds. Theories of Race and Racism: A Reader. London: Routledge, 2009.

Blackmon, Douglas A. Slavery by Another Name: The Re-Enslavement of Black Americans from the Civil War to World War II. New York: Anchor Books, 2009.

Bonilla-Silva, Eduardo. Racism without Racists: Color-blind Racism and the Persistence of Racial Inequality in America. New York: Rowman \& Littlefield Publishers, Inc., 2014.

Branch, Taylor. Parting the Waters: America in the King Years, 1954-63. New York: Touchstone, 1988.

Dudziak, Mary L. Cold War Civil Rights: Race and the Image of American Democracy. Princeton, NJ: Princeton University Press, 2000.

Edwards, Clarence. "Race and the Police." National Policing Foundation, February 8, 2016, https://www.policefoundation.org/race-andthe-police/.

Emirbayer, Mustafa, and Matthew Desmond. The Racial Order. Chicago: The University of Chicago Press, 2015.

Fassin, Didier. Enforcing Order: An Ethnography of Urban Policing. Malden, MA; Cambridge: Polity Press, 2013.

Fields Karen E., and Barbara J. Fields. Racecraft: The Soul of Inequality in American Life. London; New York: Verso, 2012.

Garrow, David J. Bearing the Cross: Martin Luther King, Jr., and the Southern Christian Leadership Conference. New York: Quill, 1999.

Gonzalez Van Cleve, Nicole. Crook County: Racism and Injustice in America's Largest Criminal Court. Stanford: Stanford University Press, 2016. 
The Graduate History Review 9, no. 1 (2020)

Gould, Stephen Jay. The Mismeasure of Man. New York: W. W. Norton \& Company, Inc., 1996.

Grossman, James R. Land of Hope: Chicago, Black Southerners, and the Great Migration. Chicago and London: The University of Chicago Press, 1989.

Hall, Jacquelyn Dowd. "The Long Civil Rights Movement and the Political Uses of the Past." The Journal of American History 91, no. 4 (Mar., 2005): 1233-1263.

Haney-Lopez, Ian. White By Law. New York; London: New York University Press, 2006.

Hinton, Elizabeth. "'A War within Our Own Boundaries': Lyndon Johnson's Great Society and the Rise of the Carceral State." The Journal of American History 100 (June, 2015): 100-12.

Hirsch, Arnold R. Making the Second Ghetto: Race and Housing in Chicago, 1940-1960. Chicago and Urbana: The University of Chicago Press, 1985.

Horne, Gerald, Fire This Time: The Watts Uprising and the 1960s. Charlottesville, VA: University of Virginia Press, 1995.

Jordan, Winthrop. White Over Black: American Attitudes Toward the Negro, 1550-1812. Kingsport, TN: The University of North Carolina Press, 1968.

King, Jr., Martin Luther.

Why We Can't Wait. New York; Evanston; and London: Harper \& Row Publishers, 1964.

Where Do We Go From Here: Chaos or Community?. New York, Beacon Press, 1967.

Kruse, Kevin M. and Thomas J. Sugrue, eds. The New Suburban History. Chicago; London: The University of Chicago Press, 2006.

Loewen, James. Sundown Towns: A Hidden Dimension of American Racism. New York, London: The New Press, 2005.

Lott, Eric. Love and Theft: Blackface Minstrelsy and the American Working Class. New York: Oxford University Press, 1993.

Lynching in America: Confronting the Legacy of Racial Terror. The Equal Justice Initiative. December 2018, https://lynchinginamerica.eji.org/report/.

Macaig, Mike, ed. Diversity on the Force: Where Police Don't Mirror Communities. Governing: The States and Localities, September 2015,

http://images.centerdigitaled.com/documents/policediversityrepo rt.pdf. 
Massey, Douglas S., and Nancy A. Denton, American Apartheid: Segregation and the Making of the Underclass. Cambridge, London: Harvard University Press, 1993.

May, Gary. Bending Toward Justice: The Voting Rights Act and the Transformation of American Democracy. New York: Basic Books, 2013.

Moody, Anne. Coming of Age in Mississippi. New York: Random House, 1968.

Morris, Aldon D. Origins of the Civil Rights Movement: Black Communities Organizing for Change. New York: The Free Press, 1984.

Mumford, Kevin. Newark: A History of Race, Rights, and Riots in America. New York; London: New York University Press, 2007.

Nevels, Cynthia Skove. Lynching to Belong: Claiming Whiteness Through Racial Violence. College Station: Texas A\&M University Press, 2007.

Omi, Michael, and Howard Winant. Racial Formation in the United States. New York: Routledge, 2015.

Painter, Nell Irvin. The History of White People. New York: W. W. Norton \& Company, Inc., 2010.

Rothstein, Richard. The Color of Law: A Forgotten History of How Our Government Segregated America. New York: W. W. Norton \& Company Ltd., 2017.

"Shielded from Justice: Police Brutality and Accountability in the United States." Human Rights Watch, July 1, 1998, https://www.hrw.org/report/1998/07/01/shielded-justice/policebrutality-and-accountability-united-states.

Sitkoff, Harvard. The Struggle for Black Equality. New York: Hill and Wang, 1981.

Sugrue, Thomas J. The Origins of the Urban Crisis: Race and Inequality in Postwar Detroit. Princeton and Oxford: Princeton University Press, 2005.

-Sweet Land of Liberty: The Forgotten Struggle for Civil Rights in the North. New York: Random House, 2009.

Stampp, Kenneth M. The Peculiar Institution: Slavery in the Ante-Bellum South. New York: Vintage, 1956.

Trouillot, Michel-Rolph, Silencing the Past: Power and the Production of History. Boston: Beacon Press, 1995.

Van Cleve, Nicole Gonzales. Crook County: Racism and Injustice in America's Largest Criminal Court Stanford, California: Stanford University Press, 2016. 
The Graduate History Review 9, no. 1 (2020)

Wells, Ida B. Southern Horrors, Lynch Law in All Its Phases. New York, 1892.

White, Deborah Gray. Too Heavy A Load: Black Women in Defense of Themselves, 1894-1994. New York; London: W. W. Norton \& Company, 1999.

Wicker, Tom, introduction. Report of National Advisory Commission on Civil Disorders: New York

Times Edition. New York: E. P. Dutton \& Co., Inc, 1968.

Wilentz, Sean, introduction. The Kerner Report: The National Advisory Commission on Civil Disorders. Princeton, Oxford; Princeton University Press, 2016.

\section{Digital/Online Resources}

DATA USA. https://datausa.io/profile/geo/new-castle-pa/\#housing. Lawrence County Memoirs.

http://www.lawrencecountymemoirs.com/lcmpages/898/joseph-ssupermarket-new-castle-pa.

Municipal Website, City of New Castle. "New Castle, Pennsylvania- Our History." http://www.newcastlepa.org/index.html.

Author. "Fine People of New Castle, I need YOUR Help," on page "New Castle Pennsylvania is my hometown." Facebook.com. January 31 , 2018. https://www.facebook.com/groups/newcastlepa/permalink/10155 $\underline{566066776051 /}$

The Old Farmer's Almanac. New Castle, Lawrence County, Pennsylvania, November $1, \quad 1970$. https://www.almanac.com/astronomy/rise/PA/New\%20Castle $\% 2$ C\%20Lawrence\%20County/197 0-11-01.

Washington Journal. "Terry Madonna on the Political Dynamics of Pennsylvania." C-Span, November 1, 2018, Pedro Echevarria, https://www.c-span.org/video/?453893-3/washington-journalterry-madonna-discusses-political-dynamics-pennsylvania. 